\title{
Towards Effective Temporary Labor Migration Schemes Report On Lebanon ANd JoRdan
}

\author{
Eugene Sensenig-Dabbous \\ Guita Hourani
}

CARIM Research Reports 2011/08 
Report on Lebanon and Jordan

EUGENE SENSENIG-DABBOUS (author), GUITA HOURANI (project manager) Notre Dame University, Lebanon

\author{
CARIM \\ EURO-MEDITERRANEAN CONSORTIUM FOR APPLIED RESEARCH ON INTERNATIONAL \\ MIGRATION \\ RESEARCH REPORT, CARIM-RR 2011/08 \\ BADIA FIESOLANA, SAN DOMENICO DI FIESOLE (FI)
}

This publication has been written in the framework of the partnership with the International Organisation on Migration (IOM) and the International Labour Organisation (ILO). 


\title{
(C) 2011, European University Institute \\ Robert Schuman Centre for Advanced Studies
}

This text may be downloaded only for personal research purposes. Any additional reproduction for other purposes, whether in hard copies or electronically, requires the consent of the Robert Schuman Centre for Advanced Studies.

Requests should be addressed to carim@eui.eu

If cited or quoted, reference should be made as follows:

[Full name of the author(s)], [title], CARIM Research Reports [series number], Robert Schuman Centre for Advanced Studies, San Domenico di Fiesole (FI):European University Institute, [year of publication].

THE VIEWS EXPRESSED IN THIS PUBLICATION CANNOT IN ANY CIRCUMSTANCES BE REGARDED AS THE OFFICIAL POSITION OF THE EUROPEAN UNION

\author{
European University Institute \\ Badia Fiesolana \\ I - 50014 San Domenico di Fiesole (FI) \\ Italy \\ http://www.eui.eu/RSCAS/Publications/ \\ http://www.carim.org/Publications/ \\ http://cadmus.eui.eu
}




\section{CARIM}

The Euro-Mediterranean Consortium for Applied Research on International Migration (CARIM) was created at the European University Institute (EUI, Florence), in February 2004 and co-financed by the European Commission, DG AidCo, currently under the Thematic programme for the cooperation with third countries in the areas of migration and asylum.

Within this framework, CARIM aims, in an academic perspective, to observe, analyse, and forecast migration in Southern \& Eastern Mediterranean and Sub- Saharan Countries (hereafter Region).

CARIM is composed of a coordinating unit established at the Robert Schuman Centre for Advanced Studies (RSCAS) of the European University Institute (EUI, Florence), and a network of scientific correspondents based in the 17 countries observed by CARIM: Algeria, Chad, Egypt, Israel, Jordan, Lebanon, Libya, Mali, Mauritania, Morocco, Niger, Palestine, Senegal, Sudan, Syria, Tunisia, and Turkey.

All are studied as origin, transit and immigration countries. External experts from the European Union and countries of the Region also contribute to CARIM activities.

CARIM carries out the following activities:

- Mediterranean and Sub-Saharan migration database;

- Research and publications;

- Meetings of academics and between experts and policy makers;

- Migration Summer School;

- Outreach.

The activities of CARIM cover three aspects of international migration in the Region: economic and demographic, legal, and socio-political.

Results of the above activities are made available for public consultation through the website of the project: www.carim.org

For more information:

Euro-Mediterranean Consortium for Applied Research on International Migration

Robert Schuman Centre for Advanced Studies (EUI)

Convento

Via delle Fontanelle 19

50014 San Domenico di Fiesole

Italy

Tel: +390554685878

Fax: + 390554685755

Email: carim@eui.eu

\section{Robert Schuman Centre for Advanced Studies}

http://www.eui.eu/RSCAS/ 


\section{Introduction}

Migration policy is one of the fields least scrutinized in the Arab world. Responding to international economic trends, policy makers, social partners, and civil society players in Jordan and Lebanon have come to the realization that certain labour market bottlenecks can only be overcome by bringing in foreign workers. This has led to a significant immigration of laborers from a wide variety of countries and forced all relevant participants in the policy making process to renew their interest in coordinated temporary labour migration schemes. Both in Jordan and Lebanon, experts and policy makers alike see opportunities in these schemes that can help them meet the changing demands in their labour markets without permanently adding to their populations and labour forces. In the countries of origin, reciprocally, temporary labour migration schemes are intended to allow governments to alleviate pressures on their labour markets in the short and medium-term, and also let them reap the benefits of migration, through remittances and skill acquisition.

In this study the authors will consider, based on a tripartite approach, whether the interests of employers and workers organizations coincide with those of governments in designing and implementing temporary migration schemes. The internationally codified rights of migrant workers to equality and non-discrimination and to their integration into societies and workplaces will be compared to the realities on the ground in Lebanon and Jordan. Have the limited provisions for protecting employees' rights and a lack of their integration into the host societies negatively affected policy goals, closely linked to social cohesion? Does the effective protection of migrant workers contradict the needs of the indigenous populations in Lebanon and Jordan in general? Can the empowerment of the migrants themselves and their inclusion into the tripartite decision making process facilitate migration policy reform? Which social players can - and have - step in if the state and social partners neglect those roles foreseen for them by the international organizations dealing primarily with migrant labour, first and foremost the International Labour Organization (ILO)?

This report is based on the following mandate from the ILO. "In the Jordanian and Lebanese cases, although the migration of Egyptian, Syrian, Sudanese and Iraqi workers is long standing and indeed, difficult to control, this study (shall be) concerned with temporary migration schemes that have been put in place for workers hailing from other regions, particularly from southern and eastern Asian countries. For the most part these latter workers can be found in domestic servitude and as workers employed in the Qualified Industrial Zones in Jordan. For both these categories of workers problems with regard to their protection (shall be) highlighted."

The survey of temporary labour migration will be divided into two parts. A brief overview of Jordan is intended to illustrate how - despite the country's lack of a truly competitive democratic system, which would guarantee both the social partners and the migrant workers themselves full democratic rights - certain progress has been made. The reality in Jordan will be superimposed on Lebanon. In a more extensive study, an attempt will be made to determine whether the implementation of international norms, be they of a legally binding, or simply ethically and politically compelling nature, have led to similar progress in the temporary migration policy field.

Special emphasis will be placed on the provisions in ILO and UN instruments as well as the ILO Multilateral Framework on Labour Migration. Other international policy instruments developed by the social partners (organized labour federations and the international employers associations) will also be considered, along with the more recent impact of global civil society.

Finally, the study will take a ten year old survey carried out by Ray Jureidini (Women Migrant Domestic Workers in Lebanon), and published by the ILO in 2002, as a point of departure. Through the use of an extensive literature review and interviews with key players (diplomats, NGO activists, policy consultants and researchers) this survey will be updated to reflect the reality at the beginning of the current decade. Furthermore, the emphasis on the role of the respective social partners and civil 
society players will not only illustrate what went wrong, but also how all relevant groups in society including the migrants themselves - can be involved in evaluating and improving the situation.

As opposed to the situation in other regions in which similar studies have been carried out, significant difficulties do exist in the Middle East which have partially impeded the above mentioned steps in this policy evaluation endeavour. These include a denial of access to updated, reliable, and significant data on the recruitment and employment of temporary workers; a lack of a transparent and accountable policy on access to information on the steps that go into the policy making process (agenda setting, decision making, implementation); and limited or no open access to the respective documents of the social partners. It should be pointed out here that the civil society players have proven to be the most cooperative, reflecting their new role in augmenting - or even replacing - the historically relevant tripartite cooperation of government, business, and labour in this field. Finally, it should be pointed out that it has proven impossible to gain access to any information on the role which temporary labour migrants themselves play in this policy development and implementation process. Nascent research on the often informal or clandestine organizational work of immigrants in Jordan and Lebanon does exist. This very rudimentary information could not, however, be utilized by the researchers because of a lack of rigours standards to date in its collection and evaluation. In those limited cases in which anecdotal evidence and hearsay has indeed been used as a source, this has been properly noted by the authors.

\section{JORDAN}

\section{Temporary labour migration schemes in Jordan}

\section{Introduction}

Labour migration is a transnational process and neither the country of origin nor the receiving country are in a position to resolve all the issues alone. Inter-State cooperation in managing labour migration is essential and involves three levels: the bilateral, regional, and multilateral.

Governments at all points on the migration spectrum increasingly recognize the potential of regulatory mechanisms to maximize the positive impact of labour migration. Many sending and receiving countries are developing their regulatory capacities to manage labour mobility by considering the interests of respective governments, societies, and the migrants themselves.

Jordan is a country of both immigration and emigration. International and regional conflicts made it a center for settlement and migration. Due to the high level of unemployment and poverty, Jordanians started to emigrate from Jordan looking for better opportunities of work, especially in the Arab gulf countries. This process resulted in an increased demand in importing a foreign labour force to Jordan to respond to the developing market needs.

Jordan became the recipient of unskilled and semi-skilled workers to fill the shortages mainly in construction, domestic work, and the service sectors. The immigrant manpower mainly works in the "3D" jobs i.e.” dirty, dangerous, difficult”, not socially rewarded, badly paid with discriminatory wage rates.

Many demographical and economic factors have played a role in keeping Jordan a prime destination country for immigrant Arab workers as well as for non-Arab foreign workers. We may name some of these factors such as:

- Pan-Arabism inheritance: open borders to Arab migrants.

- Legacy of the rentier state: migrants as redistribution in return of allegiance.

- $\quad$ Liberalization of economy, privatization: manpower needs. 
This survey is divided into three sections; the first section deals with international conventions and protocols, with their related policies and the ratification thereof, mainly in Jordan in particular, but also the Arab world in general, where it relates to human rights and labour migration schemes. The second section tackles the national policies and framework in collaboration with the Jordanian government and social partner organizations. The third section compares the international and national norms to the reality on the ground in the Jordanian case, emphasizing the gaps identified between the two.

\section{International guidelines}

\section{I.A. UN Organizations}

The International Organization for Migration (IOM) defines migration as "a process of moving, either across an international border, or within a State. It is a population movement, encompassing any kind of movement of people, whatever its length, composition and causes; it includes migration of refugees, displaced persons, uprooted people, and economic migrants.” (Glossary on Migration, International Migration Law 2004 paper $^{1}$ ).

The IOM World Migration Report (2008) defines circular migration as "the fluid movement of people between countries, including temporary or long-term movement which may be beneficial to all involved, if occurring voluntarily and linked to the labour needs of countries of origin and destination". Newland and Agunias identify circular migration as "a continuing, long-term, and fluid pattern of human mobility among countries that occupy what is now increasingly recognized as a single economic space". Both take for granted that circular migration provides a win-win situation for the countries involved as well as for the migrants.

The UN Migrant Workers Convention defines a seasonal migrant worker as "a migrant worker whose work, or migration for work, that is dependent on seasonal conditions and is performed only during part of the year", so we would find that most of the seasonal workers are those hired in the areas of agriculture, construction, or tourism, primarily during the respective holiday seasons. On the other hand, temporary migrant workers are those who work in a destination country for definite periods, normally under a labour contract with an enterprise or an individual employer ${ }^{2}$.

The globalization of labour markets around the world has highlighted the need for coordinated action. As the ILO states with respect to a need for international codification: "Across the world, millions of people are on the move - doing jobs ranging from menial labour such as harvesting to computer programming. Combined, their numbers would equal the fifth most populous country on the planet. The number of migrants crossing borders in search of employment and human security is expected to increase rapidly in the coming decades due to the failure of globalization to provide jobs and economic opportunities. The ILO sees today's global challenge as forging the policies and the resources to better manage labour migration so that it contributes positively to the growth and development of both home and host societies, as well as to the well being of the migrants themselves. In 2004, the International Labour Conference of the ILO adopted a Multilateral Framework on Labour Migration which is part of a plan of action for migrant workers agreed by ILO constituents. The Framework is part of an ILO plan of action which aims at better managing labour migration so that it contributes positively to the growth and development of both home and host societies, as well as to the well being of the migrants' themselves”3.

\footnotetext{
${ }^{1}$ http://www.iom.int/jahia/webdav/site/myjahiasite/shared/shared/mainsite/published_docs/serial_publications/Glossary_eng.pdf)

${ }^{2}$ http://www.radio1812.net/circular-migration-\%E2\%80\%93-new-form-temporary-labour-migration

${ }^{3}$ http://www.ilo.org/global/topics/labour-migration/lang--en/index.htm
} 
The United Nations Educational, Scientific and Cultural Organization (UNESCO) acknowledges the wide variety of categories for the definition of migration depending on its socio-economic, political and legal determinants relevant to every country. It thus offers a list of common categorizations of international migrants as follows: "temporary labour migrants, highly skilled and business migrants, irregular migrants, forced migration, family members and return migrants. The following research revolves around the first concept, i.e.: labour migrants, also referred to as guest workers, overseas contract workers, or economic migrants, to designate those "people who migrate for a limited period of time in order to take up employment and send money home",

\section{I.B. UN Conventions (Others)}

The Global Migration Group (GMG) is an inter-agency group bringing together heads of agencies which seek to promote the wider application of all relevant international and regional instruments and norms relating to migration, and to encourage the adoption of more coherent, comprehensive and better coordinated approaches to the issue of international migration. The GMG is particularly concerned to improve the overall effectiveness of its members and other stakeholders in capitalizing upon the opportunities and responding to the challenges presented by international migration.

The GMG was established by the United Nations Secretary-General in early 2006 in response to a recommendation of the Global Commission on International Migration for the establishment of a highlevel inter-institutional group of agencies involved in migration-related activities. The GMG was created by building on an existing inter-agency group with a more limited membership, the Geneva Migration Group, which was established in April 2003.

The GMG meets at regular intervals. The chair is held on a rotating basis by the executive heads of its member organizations. The first meeting of the GMG took place on May 9th, 2006 and was chaired by the Secretary General of UNCTAD. All GMG members have contributed actively to preparations for the 2006 General Assembly High-level Dialogue on International Migration and Development ${ }^{5}$.

Of particular relevance is the UN "International Convention on the Protection of the Rights of All Migrant Workers and Members of Their Families." The new Convention, adopted by the UN in 1990 and now ratified by 22 states, is considered as an advancement on basic principles regarding migrant labourers laid down by two ILO Conventions on migrant workers adopted over the last several decades prior to its inception.

The Convention's entry into force resulted from the promotional Global Campaign effort forged by a unique alliance of three United Nations agencies, the Office of the High Commissioner for Human Rights (OHCHR), the International Labour Organization (ILO) and the United Nations Educational, Scientific and Cultural Organization (UNESCO), with the participation of the International Organization for Migration (IOM) and 10 non-governmental organizations concerned with protecting the rights of migrant workers. ${ }^{6}$.

With the increase in the migration movements across countries, the UN bodies attempted to create an international framework that regulates inter-state dynamics in such a way to safeguard the dignity and the rights of the human beings. The UN Convention on the Protection of the Rights of all Migrant Workers and Members of their Families constitutes an international guideline for the prevention and elimination of all forms of exploitation of migrant workers since the moment of their departure from home country until their return. It encourages efforts to end their illegal, clandestine or undocumented employment or trafficking. It also introduces "a set of binding international standards to address the

\footnotetext{
${ }^{4}$ http://www.unesco.org/most/migration/glossary_migrants.htm

${ }^{5}$ http://www2.ohchr.org/english/bodies/cmw/GMG.htm

${ }^{6}$ http://www.ilo.org/global/about-the-ilo/press-and-media-centre/insight/WCMS_075619/lang--en/index.htm
} 
treatment, welfare and human rights of both documented and undocumented migrants, as well as the obligations and responsibilities on the part of sending and receiving States" (UN Press Release L/T/4371, Convention on Protection of Rights of Migrants Workers) ${ }^{7}$.

Furthermore, the Convention also imposes certain obligations on State parties to promote "sound, equitable, humane and lawful conditions" for all migrant workers and members of their families. These obligations include developing national policies on migration, exchanging information with other State parties and granting employers, workers and their organizations/offices access to information on relevant laws and regulations, as well as generally assisting migrant workers and their families ${ }^{8 .}$

Labour law, industrial relations and social dialogue are at the core of ILO member States' economic and social organization. Sound industrial relations and effective social dialogue are a means to promote better wages and working conditions as well as peace and social justice. As instruments of good governance they foster cooperation and economic performance, helping to create an enabling environment for the realization of the objective of Decent Work at the national level ${ }^{9}$.

\section{I.C. Regional Level (Arab Human Rights Agreement)}

The Cairo Declaration of Human Rights in Islam (CDHRI) is a declaration of the member states of the Organization of the Islamic Conference, which provides an overview on the Islamic perspective on human rights, and affirms Islamic Shari'ah as its sole source.

CDHRI declares its purpose to be "general guidance for Member States [of the OIC] in the Field of human rights". This declaration is usually seen as an Islamic counterpart of and a response to the Universal Declaration of Human Rights (UDHR).

Predominantly Muslim countries, like Sudan, Pakistan, Iran, and Saudi Arabia, frequently criticized the Universal Declaration of Human Rights for its perceived failure to take into account the cultural and religious context of non-Western countries. In 1981, the Iranian representative to the United Nations, Said Rajaie-Khorassani, articulated the position of his country regarding the Universal Declaration of Human Rights, by saying that the UDHR was "a secular understanding of the Judeo-Christian tradition", which could not be implemented by Muslims without trespassing the Islamic law.[1]

The declaration was adopted on August 5, 1990 by 45 foreign ministers of the Organization of the Islamic Conference to serve as guidance for the member states in the matters of human rights ${ }^{10}$.

The Declaration starts by forbidding "any discrimination on the basis of race, colour, language, belief, sex, religion, political affiliation, social status or other considerations". It continues on to proclaim the sanctity of life, and declares the "preservation of human life" as "a duty prescribed by the Shariah". In addition the CDHRI guarantees "non-belligerents such as old men, women and children", "wounded and the sick" and "prisoners of war", the right to be fed, sheltered and access to safety and medical treatment in times of war.

The CDHRI declaration prohibits to force anybody "to change his religion to another religion or to atheism", but it gives the individual no freedom to change his religion or belief.

The Declaration protects each individual from arbitrary arrest, torture, maltreatment and/or indignity. Furthermore, no individual is to be used for medical or scientific experiments. It also prohibits the taking of hostages of any individual "for any purpose" whatsoever. Moreover, the CDHRI guarantees the presumption of innocence; guilt is only to be proven through a trial in "which

\footnotetext{
${ }^{7}$ http://www.un.org/News/Press/docs/2003/LT4371.doc.htm

${ }^{8}$ http://www.ilo.org/ilolex/cgi-lex/convde.pl?C097

${ }^{9}$ http://www.ilo.org/public/english/dialogue/ifpdial/index.htm

${ }^{10}$ http://europenews.dk/en/node/3847
} 
he [the defendant] shall be given all the guarantees of defense". The Declaration also forbids the promulgation of "emergency laws that would provide executive authority for such actions.

The Declaration also emphasizes the "full right to freedom and self-determination", and its opposition to enslavement, oppression, exploitation and colonialism. The CDHRI declares the rule of law, establishing equality and justice for all. The CDHRI also guarantees all individuals the "right to participate, directly or indirectly in the administration of his country's public affairs". The CDHRI also forbids any abuse of authority.

The Declaration grants individuals the right to express their opinion freely. It encourages them to propagate that which is right and good. However, it forbids the misuse of this right in order to "violate sanctities and the dignity of Prophets", "undermine moral and ethical values or disintegrate", "arouse nationalistic or doctrinal hatred" or commit an "incitement to any form of racial discrimination". The CDHRI concludes that all rights and freedoms mentioned are subject to the Islamic Shariah, which is the declaration's sole source ${ }^{11}$.

\section{I.D. Social Partner}

The most relevant organized labour federations and a variety of employers associations have joined hands with governments around to world to coordinate their efforts in the fields of social policy. Based on this "social partnership," big business and big labour have been dubbed the "social partners."

\section{Employers organizations}

Since its creation in 1920, the International Organization of Employers (IOE) has been recognized as the only organization at the international level that represents the interests of business in the labour and social policy fields. Today, it consists of 148 national employer organizations from 141 countries from all over the world (November 2010) ${ }^{12}$.

The mission of the IOE is to promote and defend the interests of employers in international arena, particularly in the International Labour Organization (ILO), and to this end works to ensure that international labour and social policy promotes the viability of enterprises and creates an environment favourable to enterprise development and job creation. At the same time it acts as the Secretariat to the Employers' Group at the ILO International Labour Conference, the ILO Governing Body and all other ILO-related meetings.

In order to ensure that the voice of business is heard at the international and national level, the IOE is actively engaged in the creation and capacity building of representative organizations of employers, particularly in both the developing world and those countries in transition to the market economy.

The IOE is the permanent liaison body for the exchange of information, views and experience among employers throughout the world. It acts as the recognized channel for the communication and promotion of the employer point of view to all United Nations agencies and other international organizations $^{13}$.

\footnotetext{
${ }^{11}$ Ibid

12 http://www.ioe-emp.org/

${ }^{13}$ Ibid
} 


\section{International Chamber of Commerce (ICC)}

The ICC is the largest, most representative business organization in the world. Its hundreds of thousands of member companies in over 130 countries have interests spanning every sector of private enterprise.

A world network of national committees keeps the ICC International Secretariat in Paris informed about national and regional business priorities. More than 2,000 experts drawn from ICC's member companies feed their knowledge and experience into crafting the ICC stance on specific business issues.

The ICC has permanent observer status with the United Nations. The UN, the World Trade Organization, and many other intergovernmental bodies, both international and regional, are kept in touch with the views of international business through ICC ${ }^{14}$.

All business disputes, whether or not of an international character, may be referred to ADR proceedings pursuant to these Rules. The provisions of these Rules may be modified by agreement of all of the parties, subject to the approval of ICC.

ICC has over eight decades of experience in devising rules to govern and facilitate the conduct of international business. These include those designed to resolve the conflicts that inevitably arise in trading relations ${ }^{15}$.

The ICC ADR rules are the result of discussions between dispute resolution experts and representatives of the business community from 75 countries. Their purpose is to offer business partners a means of resolving disputes amicably, in the way best suited to their needs. A distinctive feature of the Rules is the freedom the parties are given to choose the technique they consider most conducive to settlement. Failing to agree on the method to be adopted, the fallback shall be mediation.

As an amicable method of dispute resolution, ICC ADR should be distinguished from ICC arbitration. They are two alternative means of resolving disputes, although in certain circumstances they may be complementary. For instance, it is possible for parties to provide for ICC arbitration in the event of failure to reach an amicable settlement. Similarly, parties engaged in arbitration may turn to ICC ADR if their dispute seems to warrant a different, more consensual approach. The two services remain distinct, however, each administered by a separate secretariat based at ICC headquarters in Paris.

The ICC ADR Rules, which replace the 1988 ICC Rules of Optional Conciliation, may be used in domestic as well as international context ${ }^{16}$.

Labour law, industrial relations and social dialogue are at the core of ILO member States' economic and social organization. Sound industrial relations and effective social dialogue are a means to promote better wages and working conditions as well as peace and social justice. As instruments of good governance they foster cooperation and economic performance, helping to create an enabling environment for the realization of the objective of Decent Work at the national level ${ }^{17}$.

The International Islamic Mediation \& Arbitration Centre (IMAC) is an independent international institution established pursuant to resolution by The Arab Chamber of Commerce \& Industry signed on 31st of July 2008 in Hong Kong and consultation with and The International Chamber of Commerce. Its objectives are:

- Conducting mediations and arbitrations;

- Promotion of international commercial arbitration;

\footnotetext{
${ }^{14}$ http://en.wikipedia.org/wiki/International_Chamber_of_Commerce

${ }^{15}$ http://www.iccwbo.org/uploadedFiles/Court/Arbitration/other/adr_rules.pdf

${ }^{16}$ Ibid

${ }^{17}$ http://www.ilo.org/public/english/dialogue/ifpdial/index.htm
} 
- Coordinating the activities of, and offering assistance to, existing arbitration institutions in the region;

- Providing assistance to ad hoc arbitrations, including acting as appointing authority, particularly in cases where they are taking place in accordance with the UNCITRAL Rules;

- Providing assistance in the enforcement of arbitral awards;

- Providing assistance in the settlement of disputes ${ }^{18}$.

Arbitration proceedings administered by IMAC shall be governed by the Arbitration Rules, which essentially follow the UNCITRAL rules of arbitration. Certain aspects of these rules, however, have been modified in order to take into consideration the institutional character of arbitrations that will be conducted under the Shariah Rules of Arbitration of IMAC ${ }^{19}$.

This Code of Ethics, as adopted by the Membership Committee and approved by the Council of the Arab General Chamber of Commerce \& Industry, is intended to serve as a general guideline to the everyday conduct of every Chamber member (Corporate Members and Individual Associate Members.)

1. Chamber members should observe all rules set out in the Memorandum and Articles of Association and By-laws of the Chamber, a copy of which is availed to all members upon their joining of membership.

2. The Chamber expects each member to observe a high standard of business ethics, and to be honest in their dealings with government, officials, the public, firms or other corporations, entities, or organizations with whom the member company transacts, or is likely to transact.

3. The Chamber expects each member to observe and comply with all laws, rules, and regulations of the Special Administrative Region of Hong Kong, in which members are registered as lawful business entities.

4. Members should avoid any activities that involve or would lead to the involvement of the company in any unlawful practices. Accordingly, each member should understand the legal standards and restrictions that apply to all registered businesses in Hong Kong.

5. Members are expected to endorse the overall Chamber's mission of promoting, representing and safeguarding the interests of the Hong Kong business community. Members are expected to be reputable representatives of the Chamber and not be using the Chamber in a way which brings discredit to the Chamber.

6. Members should acknowledge that any practice or behavior of members that contradict the mission or the general interest of the Chamber may result in possible expulsion from membership upon the judgment of the Council ${ }^{20}$.

\section{Labour Organizations}

\section{International Trade Union Confederation (ITUC)}

The ITUC is the world's largest trade union federation. It was formed on November 1, 2006 out of the merger of the International Confederation of Free Trade Unions (ICFTU) and the World Confederation of Labour (WCL). The Founding Congress of the ITUC was held in Vienna and was preceded by the dissolution congresses of both the ICFTU and the WCL ${ }^{21}$.

\footnotetext{
18 http://www.arabcci.org/IMAC_aboutus.htm

${ }^{19}$ Ibid

${ }^{20}$ http://www.arabcci.org/membership.htm

${ }^{21}$ http://en.wikipedia.org/wiki/International_Trade_Union_Confederation
} 
Provision of benefits to members: Early trade unions, like Friendly Societies, often provided a range of benefits to insure members against unemployment, ill health, old age and funeral expenses. In many developed countries, these functions have been assumed by the state; however, the provision of professional training, legal advice and representation for members is still an important benefit of trade union membership

Collective bargaining: Where trade unions are able to operate openly and are recognized by employers, they may negotiate with employers over wages and working conditions.

Industrial action: Trade unions may enforce strikes or resistance to lockouts in the advancement of particular goals.

Political activity: Trade unions may promote legislation favorable to the interests of their members or workers as a whole. To this end they may pursue campaigns, undertake lobbying, or financially support individual candidates or parties (such as the Labour Party in Britain) for public office ${ }^{22}$.

Global Unions call for the establishment of a national and international regulatory architecture that would ensure economic, social and environmental sustainability. This regulatory framework should induce a shift away from financial markets' short-termism and the primacy of shareholders' value and ensure that financial markets return to their primary function (i.e. financing of the real economy). The regulatory framework should aim at limiting the negative social and environmental impacts of financial activities and give incentives to achieve full, decent employment and the transition to a low carbon economy ${ }^{23}$.

\section{World Federation of Trade Unions (WFTU)}

The WFTU was established in 1945 to replace the International Federation of Trade Unions. Its mission was to bring together trade unions across the world in a single international organization, much like the United Nations. After a number of Western trade unions left it in 1949, as a result of disputes over support for the Marshall Plan, to form the International Confederation of Free Trade Unions, the WFTU was made up primarily of unions affiliated with or sympathetic to Communist parties. In the context of the Cold War, the WFTU was often portrayed as a Soviet front organization.[3] A number of those unions, including those from Yugoslavia and China, left later when their governments had ideological differences with the Soviet Union.

The WFTU has declined precipitously in the past twenty years since the fall of the communist regimes in the Soviet Union and Eastern Europe, with many of its former constituent unions joining the $\mathrm{ICFTU}^{24}$.

In January 2006 it moved its headquarters from Prague, Czech Republic to Athens, Greece and now focuses on organizing regional federations of unions in the Third World, campaigning against imperialism, racism, poverty, environmental degradation and exploitation of workers under capitalism and in defense of full employment, social security, health protection, and trade union rights. The WFTU continues to devote much of its energy to organizing conferences, issuing statements and producing educational materials

As part of its efforts to advance its international agenda, the WFTU develops working partnerships with national and industrial trade unions worldwide as well as with a number of international and regional trade union organizations ${ }^{25}$.

\footnotetext{
${ }^{22}$ Ibid

${ }^{23}$ http://www.un-ngls.org/spip.php?page=article_s\&id_article=703

${ }^{24}$ http://en.wikipedia.org/wiki/World_Federation_of_Trade_Unions

${ }^{25}$ Ibid
} 


\section{Formal reality in Jordan}

\section{II.A. Jordanian Government level.}

\section{A.1. Laws, regulation, formal policies.}

The law imposes conditions on foreign nationals that may enter the Kingdom (law 24-1973). Thus the foreign worker can only be granted entry with a valid passport or travel document and an entry visa. There are two types of visas a single and a multiple visit visa as well single or multiple transit Visa. Visas are valid for a duration not exceeding two months and are issued by Ministry of Interiors. Visas issued by Jordanian diplomatic mission abroad are valid for one month. Transit visa are granted for a period of 72 hours. All visa duration start effectively from the day entering the Kingdom. The recruitment of foreign workers is based on the need of the market and takes into consideration the list of closed professions. The MOL decides the desired percentage of foreign worker in each economic sector taking into the consideration the policy of the gradual replacement of foreign work force by Jordanians ${ }^{26}$.

Since 1999, entry of foreign labour to the Kingdom became conditional on obtaining a work permit from the Jordanian embassy in the country of origin before arrival. Work contracts have to be obtained before departure from the Jordanian diplomatic and economical representations in the country of origin. Regular bilateral agreements govern the entry of each nationality on the Jordanian labour market, stating employment conditions and minimum salaries ${ }^{27}$.

With a relatively open-door policy for semi-skilled and low-skilled economic immigration, Jordan has devised an immigration policy apparatus that focuses on regulating the status of foreign labour and allocating quotas for their recruitment. The status of foreign nationals in Jordan varies according to activity, place of work, national origin. Arab nationals are privileged as far as entry, stay and access to citizenship.

The Law n ${ }^{\circ} 24$ of 1973 on Residence and Foreign Nationals’ Affairs, modified by Amendment n'90/1998.

Bilateral agreements: on Egyptian workers' employment (1985, 2007); on the placement of Indonesian domestic workers (2009); on manpower with the Philippines (2006), Pakistan and Sri Lanka (2007), Algeria (2004), the United Arab Emirates (2006), among others ${ }^{28}$.

\section{Law n'24 of 1973, On Residence and Foreign nationals’ affairs:}

Irregular entry is penalized with one to six months in prison or a 10 to 50 dinar-fine. Also it sanctions against carriers. Irregular stay is punished with a fine of 15 to 45 dinars each month. Employment of irregular workers is punished with a fine. The irregular worker is deported and forbidden to return for 3 years. Any other offence can be sanctioned by one week to one month-prison sentence, or at least a 10 dinar-fine. Deportation decisions can be judicially challenged, without effectiveness. Any foreign national should be registered if staying more than two weeks. Any estate rented to a foreign national should be declared ${ }^{29}$.

Migrant domestic workers are employed through private recruitment agencies specialized in bringing and employing non- Jordanian domestic women. The recruitment of foreign workers is now

\footnotetext{
${ }^{26}$ Mohamed Olwan, “Circulation and Permanent Migration: A Jordanian Perspective, CARIM-AS No 2008/34, p. 3, 7.

${ }^{27}$ Françoise Del Bel- Air, “Circulation Migration To and From Jordan: An issue of high politics, CARIM-AS No2008/20, p.4

${ }^{28}$ Mohamed Olwan, “High-skilled to and from Jordan”, CARIM-AS No 2010/05, p. 6.

${ }^{29}$ Bartolomeo, fakhoury and Perrin,” Migration Profile”,Jordan, CARIM- Nov, 2010, p. 6-7
} 
governed by a new regulation bylaw no 89of 2009. The new bylaw regulates the work of recruitment agencies taking into account human rights standards; aim to improve the living conditions of workers.

Article 3 of the bylaw stipulates that recruitment agencies must be Jordanian Limited Liability Company with a registered capital of no less than 50,000 Jordanian Dinar and its role is limited to middlemen. The new bylaw imposes penalties on violators and increases the effectiveness of labour ministry's monitoring and supervision of the recruitment agencies. Violations could be recruiting of domestic workers younger than 18 years, exploitation of the workers, the inhuman treatment and their transfer of illegal manner to other countries ${ }^{30}$.

Chapter two of the Constitution establishes a number of workers' rights, including and equitable working conditions; limited working hours per week; weekly and annual paid rest; special compensation given to workers supporting families and on dismissal, illness, old age and emergencies arising out of the nature of the work; special condition for the employment of women and juveniles; equal pay for equal work; free trade unions origination within the limits of the law ${ }^{31}$.

In Jordan, National Assembly (Majlis al Umma) is competent to adopt labour legislation. The legal framework is mainly comprised of the Jordanian Labour Law of the year 1996 and its amendments. This Code repeals the Labour Code of 1960, and all amendments made thereto. It governs labour affairs in Jordan. The provisions of the law apply to all employees and employers as defined by Article 2 of the Law. This law was completed by regulations, instructions and decisions issued in accordance with the above labour law. Based on ratified Conventions, amendments to the labour law were adopted on 28 August 2002.

These amendments concern some important matters mainly:

- The extension of the coverage of the labour law to some categories of workers in the agriculture sector; the establishment of private employment offices organizing the recruitment of foreign domestic workers and control of these offices by labour inspectors. This will extend the control by the Ministry of Labour of the recruitment and working conditions of these workers;

- The protection of workers from dismissal due to economic and technical factors by adoption of detailed regulation;

- The regulation of working hours;

- The inter-relation between employers' and workers' organizations.

The following Acts may be considered key:

- Regulation No. 23 of 1966, as amended, issuing rules governing the public service defines individual labour relations, paid leave, compensation, temporary assignment and termination of service;

- Order of Minister of Labour to establish committees to study the cases of termination or suspension of contracts of employment on the basis of the provisions of section 31 of the Labour Code. This Order establishes committees in each governorate where there is a Directorate for work and employment, so as to study the cases of termination of contracts of employment for undetermined periods or cases of suspending such contracts for economic or technical reasons as provided for in section 31 of the Labour Code;

- Act No. 36 of 1997 concerning work permit fees for non-Jordanian workers, issued under Article 12 of the Labour Code of 1996. This Act provides for the fees to be paid by the employer for the delivery of work permits;

\footnotetext{
${ }^{30}$ Mohamed Olwan, “Gender and Migration in Jordan”, CARIM-AS No 2010/66, p. 6

31 http://www.ilo.org
} 
- Act No. 56 of 1996 concerning labour inspection, promulgated under Article 7 of the Labour Code ${ }^{32}$;

- Industrial accidents and occupational diseases instructions of 1993. Instructions issued by the social security authority which prescribe the procedures to be observed in the event of such an accident, and provide for medical assistance to victims and financial compensation for disability resulting from an industrial accident or the contraction of an occupational disease;

- Act No. 19 of 2001 on Social security. This law provides for the establishment of the General Social Security Institution, which should provide social insurance for all workers under sixteen with certain exceptions (seafarers, domestic servants, agricultural workers). It deals also with Labour injuries and occupational diseases, Old Age, Disability and Death benefits ${ }^{33}$.

\section{A.2. Institutions, Ministries, Authorities}

According to MOL there were 335,707 (280,505 males and 55,202 females) registered migrant workers. The percentage of the foreign workforce to the national one was $23,9 \%^{34}$. The guest workers were estimated by a quarter million as a legal foreign labour force. Legal and illegal were estimated to reach almost a million.

The foreign workers represent a fundamental component of the Jordanian labour market especially in the Qualified Zones (QIZ) and the Aqaba Special Economic Zone. Although the law governing international migration to Jordan is becoming more and more restrictive, the Jordanian labour force is still seeking to attract a bigger foreign work force. The QIZ program did create some job opportunities but has also increased labour immigration flows into the country to meet private investors' demands in terms of skilled and motivated workforce ${ }^{35}$.

Access to Employment: modified in 2007.

It is linked to a stay permit and a work permit. Employer's statement; National preference + Arab priority. Professional activity, as employee or not, should not compete with Jordanians' activities (certificate to be obtained from authorities). Liberal professions, government employment and a list of professions are reserved for nationals. Migrant workers usually arrive with a 3 year renewable contract. According to the law, after a year, applications for a residence permit and work permit have to be submitted to the labour Ministry ${ }^{36}$.

Within the framework of a clear defined bilateral agreement between the Jordan-US free trade agreement the US imposes that foreign worker at QIZ would be covered by the Jordanian labour law's provisions, in terms of work contract, minimum wage, work schedule and conditions, social security and health coverage. Yet the disrespect of labour law's provision by QIZ Factories managers, the foreign workers are frequently subject to right abuses.

Foreign workers in QIZ are recruited through the Jordan Investment board, which is a government body with a financial and administrative independence. The employer wanting to bring foreign worker to Jordan must submit an application for MOL in case of domestic worker and to the board in case of QIZ workforce ${ }^{37}$.

\footnotetext{
32 Ibid

33 Ibid

${ }^{34}$ Op. cit, p. 2

${ }^{35}$ Francoise Del Bel air, “Circulation Migration To and From Jordan”, CARIM- AS No 2008/50, p. 5

${ }^{36}$ Bartolomeo, fakhoury and Perrin,” Migration Profile”,Jordan, CARIM- Nov, 2010, p. 7

${ }^{37}$ Mohamed Olwan, “Gender and Migration in Jordan”, CARIM-AS No 2010/66, p. 6
} 
All Non-Arab migrants entering the Kingdom are subject to a residency permit and a valid work permit. Otherwise they must pay an annual fee and risk to deportation. Renewal conditions are subject to the Jordanian laws ${ }^{38}$.

\section{A.3 Specific references to ratification of international guidelines}

Jordan has entered in addition to a number of bilateral agreements with sending countries it has signed protocol with high income receiving countries. The significant terms of these agreements are:

- The party states undertake to reinforce cooperation in the various field concerning workforce issues and to organize recruitment and worker movement

- A particular emphasis on vocational training, exchange of expertise and information. The protocol between the Jordanian and Algerian government focuses on the exchange of research, information and labour law as well as model of experiments. One of the main features is facilitation of the recruitment process between two countries. Another feature is to establishment of join committee to oversee the application of the relevant agreement.

- Among other features the creation of recruitment bureau to deal with recruitment needs for employer. In general most of them deal with relevant authority in one state informing its counterpart of any employment offers it has received. The employer is allowed to appoint a representative in the sending country to oversee the recruitment process. It is very interesting that these agreements never clearly point out to the high skilled workers that they are drafted generally to cover the receiving country's labour needs ${ }^{39}$.

Jordan has agreed to the "Cairo Declaration on Human Rights in Islam" issued in 1990 by foreign ministers of Muslim countries. The declaration is a guiding document that does not require ratification. Jordan also acceded to the "Arab Charter of Human Rights/Amended" prepared by the Arab Summit in Tunisia in May $2004^{40}$.

\section{B. Actual Implementation}

\section{NGOs}

Most types of Human Rights institutions exist in Jordan, such as national institutions, parliamentary committees and non-governmental organizations. The National Center for Human Rights was established by Law No. 75/2002, which aims at enhancing human rights principles in Jordan, strengthening human rights culture at the levels of thought and practice, and adhering to nondiscrimination among citizens. The Center's jurisdiction includes: revision of existing legislation, dealing with complaints pertaining to human rights, confronting any violations by correcting them, or referring them to executive, legislative or proper judicial authorities in order to stop these violations and to eliminate their impact. The Center publishes an annual report, specialized report and a research journal. It also established a web site (www.nchr.org.jo). It has also attained observer status on the international coordination committee.

The parliament has a committee for freedoms and citizen rights that takes important initiatives in monitoring the condition of prisoners and detainees held by security agencies, as well as Jordanian political prisoners in Israel.

\footnotetext{
${ }^{38}$ Françoise Del Bel- Air, “Circulation Migration To and From Jordan: An issue of high politics, CARIM-AS No2008/20, p.5-6

39 Mohamed Olwan, “High-skilled to and from Jordan”, CARIM-AS No 2010/05, p. 6.

${ }^{40}$ http://www.arabhumanrights.org/en/countries/country.aspx?cid=7
} 
Non-governmental organizations working on human rights cover a wide range of concerns such as The Arab Human Rights Organization in Jordan (1987), The Jordanian Society for Human Rights (1996). Some NGOs confine their effort to enhancement and protection of human rights, such as The Arab Center for Human Rights Training (1998), and Amman Center for Human Rights Studies (1999). Other NGOs deal with one area of freedoms, such as The National Society for Freedom and Democratic Way (1993) and The Center for Protecting the Freedom of Journalists (1999). Finally, some NGOs concentrate on supporting the rights of the most vulnerable groups like women and children, such as the International Institute for Solidarity with Women in Jordan (1998).

Seven human rights associations established in 2007 "The Jordanian "Coalition of Human Rights Organizations" that consists of the Arab Human Rights Organization. In Jordan, Amman Centre for Human Rights studies, the Jordanian Lawyers Society, Jordanian Society for Child Rights, Jordanian Human Rights Society, Arab Women's Society and Jordanian Youth Forum. Membership of the coalition is open to any interested Jordanian civil society organization. The coalition approved a code of conduct based on international principles of Human rights. The coalition considered itself part of the Arab and international civil society and of the anti-globalization movement ${ }^{41}$.

In July 2006, the "Arab Network for Election Monitoring" was established by Amman Human Rights Centre. The network includes 45 civil society organizations and institutions. It held its founding conference on November 29 and 30, approved its bylaws, and elected a president and board members. The network aims at monitoring elections according to international standards. It publishes a monthly news bulletin titled "The Electoral Observer" that covered several Arab elections. The bulletin is available at (http://intekhabat.org) ${ }^{42}$.

$90 \%$ of QIZ's companies operate in the labour intensive, semi-skilled garment manufacturing sector. The Foreign workforce is $60 \%$ of the total workforce where Asian women represent $58 \%$ (MOL data). The QIZ employ around 25,000 foreign migrant workers, where 13000 are female.

The Domestic workers constitute a large portion of migrant worker population. In 2009, Jordan was hosting 51,689 domestic workers legally. The number is growing due to the improvement in living conditions of locals, and the job performed by domestic workers are not attractive to the national workforce. Migrant domestic workers come mainly from Indonesia, Sri Lanka and the Philippines ${ }^{43}$.The culture of shame and reluctance of Jordanian to join the changing market and perform productive activities, pushed the investors and business owners to import more foreign labour.

Although migrant workers have access to free legal aid, very few of them consult a lawyer. Hundred of migrant workers flee their employers and take refuge in their respective embassies. But when found they are imprisoned and then deported. This is another way of human rights and UN convention violation ${ }^{44}$.

One of the main benefits for the country of origin of a migrant worker is the flow of remittances that the migrants send. Remittances play a very important role in the economic development of many countries. Remittances if non- Jordanians living in Jordan increased rapidly during the period 19942004 from 65 million JD representing 1.76\% of GDP in Jordan in the year 1994 to 251.1 million JD representing $2.50 \%$ of the GDP in Jordan in the year 2006, with average annual growth rate of $8.8 \%$ during 1994-2005. The remittances receiving for countries in 2006 were India (25.7 \$ billions), Philippines (14.9 \$ billions), Bangladesh (5.5 \$ billions) ${ }^{45}$.

\footnotetext{
${ }^{41}$ http://www.arabhumanrights.org/en/countries/country.aspx?cid=7

42 Ibid

${ }^{43}$ Francoise Del Bel air, “ Circulation Migration To and From Jordan”, CARIM- AS No 2008/50, p. 5

${ }^{44}$ Mohamed Olwan, “Gender and Migration in Jordan”, CARIM-AS No2010/66, p 7-8.

${ }^{45}$ Fathi Arouri, “Circular Migration in Jordan”, CARIM-AS No 2008/35, p.13, 15
} 
Among other features the creation of recruitment bureau to deal with recruitment needs for employer. In general most of them deal with relevant authority in one state informing its counterpart of any employment offers it has received ${ }^{46}$.

The employer is allowed to appoint a representative in the sending country to oversee the recruitment process. It is very interesting that these agreements never clearly point out to the high skilled workers that they are drafted generally to cover the receiving country's labour needs. The employee is guaranteed the right of seeking other employment upon termination of his/her contract, but only in accordance with the laws of receiving country. One of the few concrete outcomes is the establishment of a join committee to oversee the execution of these agreements ${ }^{47}$.

Migrant domestic workers tend to be young, unskilled, unmarried, poor, without knowledge of Arabic or English, and unaware of their rights. They live at the mercy of the employer and the recruitment agencies ${ }^{48}$.

\section{Discrepancies between Sections I. and II.}

\section{III.A. Comparison of International Norms and Formal Reality in Jordan}

Jordan is party to a considerable number of international conventions on human rights in general and on international migration specifically. International conventions and protective norms that are applicable to the exploitation of migrant workers, and to which Jordan is party include: the Convention on the Elimination of all forms of Racial Discrimination (CERD), the Convention on the Elimination of Discrimination Against Women (CEDAW), the International Covenant on Civil and Political Rights (ICCPR), the International Covenant on Economic, Social and cultural, Right (ICESR), the Convention Against Torture (CAT), and the Convention on the right of the Child (CRC).

International labour organization conventions to which Jordan is party: the Equal Remuneration Convention of 1951 (no.100), the Abolition of Forced Labour Convention of 1957 (No.105), the discrimination (employment and occupation) convention of 1958 (no.111), and equality of treatment (the Social security Convention of 1962 (no.118)

All these major conventions include human-rights norms pertinent to women, human rights of workers, and human-rights standards concerning migrants. Some conventions were ratified (CEDAW) with certain reservations related to citizenship, housing and women's mobility. Other international conventions were more relevant to the issue of migrant women but Jordan has not yet ratified them. They include the 1990 UN Convention on the Rights of ALL Migrants and their Families (ICMRW), the Freedom of Association and Protection of Right to Organize Convention (no.87), the 1981 Promotion of Collective Bargaining Convention (no.154), the 1975 Migration in Abusive Condition and the Promotion of Equality of (no.143), the 1949 Migration for Employment Convention (no.97), and the 1997 Private Employment Convention (no.81).

In Fact Jordan, like many other countries, remains reluctant to ratify international conventions that limit the state's ability to restrict the rights of migrants living and working in their territory. The Jordanian Constitution is silent on what law takes precedence in the case of discrepancies between ratified international treaties and Jordanian laws pertaining to the same subject matter. However, Jordanian courts have always preferred international treaties over Jordanian statutes.

\footnotetext{
${ }^{46}$ Mohamed Olwan, “High-skilled to and from Jordan”, CARIM-AS No 2010/05, p. 6-7

${ }^{47}$ Ibid

${ }^{48}$ Mohamed Olwan, “Gender and Migration in Jordan”, CARIM-AS No2010/66, p. 6
} 
In few cases Jordanian courts have had the occasion to apply international conventions on human rights to which Jordan is party. Nevertheless, the country's ratification of most international conventions on human rights reflects political will to work towards full implementation of international human rights standards ${ }^{49}$.

\section{B. Comparison of Formal Level (International and National Norms) to Actual Implementation}

The role of governmental institutions such as the Ministry of Interior; the Ministry of Labour; the Ministry of Foreign Affairs; the Ministry of Planning and the Department of Statistics in Jordan (DOS) is to set up rules concerning the entry and residence of foreign nationals and regulate their residence for legal periods of time. They provide estimates pertaining to the actual figures and location of foreign workers; enforce work permits' fees collection; define quotas for the employment of foreign manpower and design employment conditions and minimum salaries of foreign workers in the Jordanian labour market; set up bilateral agreements in the labour field (including the recruitment and bringing of guest workers); fight against irregular and transit immigration in, through, and from Jordan; reduce the number of undocumented workers through practices such as deportation; identify refugees and define their "status" and legal as well as social right.

One of the governmental reforms was: after decades of an "open door" policy, in 2007, Jordan initiated a protectionist policy aimed at granting certain jobs to nationals. For instance, in 2007 and 2008, the number of foreign nationals holding work permits dropped as a consequence of changes in the labour law which labelled many foreigners with a valid work permit as irregular. Following these political changes, in 2005 and 2006, 34,586 foreigners were expelled from Jordan while in 2008 5,000 Bangladeshis were repatriated. The Jordanian labour Ministry also reacted to the report published from the National Labor Committee (US organization) on the QIZ factories and their awful working conditions by taking series of measures: it increased the number of work inspectors, set up hotlines to receive complaints from migrant workers and fined a number of employers ${ }^{50}$.

The Jordanian constitution of 1 January 1952 reserves a chapter for the "rights and duties of Jordanians". This chapter includes the right to equality and non- discrimination, but it does not guarantee the principle of non- discrimination on the basis of sex. While the National Charter adopted in 1990 expressly affirms the constitutional equality of women and men, contains most of the rights omitted from the constitution, and provides a broad range of democratic freedom, it is not a legally binding document. Therefore, a constitutional amendment to incorporate equality on the basis of gender and to ban gender-based discrimination in employment is needed ${ }^{51}$.

According to census data, 342,273 foreign nationals resided in Jordan, or $7.7 \%$ of the total resident population. Among them, 191.307 were economically active or $13.2 \%$ of the total active population; of which 178,636 were employed ${ }^{52}$.

The unemployment rate of foreign nationals was estimated at $6.6 \%$ vs. 25.2\% among Jordanians. Foreign nationals came mainly from Arab Asian countries (52.5\%) and Arab African countries (30.0\%). The growing importance of Non- Arab nationals emerged: their annual average growth rate stood at $16.9 \%$ (vs. $2.5 \%$ for the total foreign population), while their proportion of the total foreign population more than doubled from $6.9 \%$ to $14.8 \%$, reaching $26.7 \%$ when only the economically active foreign population is considered.

\footnotetext{
49 Ibid, p. 2-3

${ }^{50}$ Bartolomeo, Fakhoury and Perrin,” Migration Profile”,Jordan, CARIM- Nov, 2010, p.3,10

${ }^{51}$ Op cit., p2

${ }^{52}$ Bartolomeo, Fakhoury and Perrin,” Migration Profile”, Jordan, CARIM- Nov, 2010, p. 1-2.
} 
As per their profile, foreign nationals in Jordan are: a) mainly men (59.0\%), b) young (mean age of 26.2 ), c) poorly educated (62.4\% have less than secondary level), d) employed at low occupational levels (e.g. $43.9 \%$ as craft and related trades workers and $27.8 \%$ in elementary occupations) and e) mainly working in the manufacturing (26.6\%), construction (22.5\%), and in the service sector $(17.9 \%$, of whom $82.6 \%$ employed in private households) and in the agricultural sector (11.7\%).The evolution of foreign workers holding work permits confirm the growing importance of Asian nationals as well as a parallel rise in the percentage of foreign nationals employed in the service sector (where Asian nationals are mainly employed $)^{53}$.

A special working contract prepared by the MOL governs the relationship between migrant domestic worker and the employer. The contract needs to be written in Arabic and in a language understood by the domestic worker and will be retained by MOL, the recruitment agency and the domestic worker. The contract ensures a minimum of rights and working conditions for migrant domestic workers, but it remains silent on matters such as maximum working hours, overtime pay, right to privacy, freedom of mobility and banned from marriage.

Other forms of abusing domestic workers include rape, sexual harassment, withholding of wages, seizure passports, prolongation of working hours, limits to freedom of movement even on weekends and beatings. The minimum monthly wage is JD 110 (2006) and it is far below the poverty line. The bylaw is silent on the question of wages and is still below the national minimum wage (about $200 \$)^{54}$.

Tens of thousands of female migrant domestic workers in Jordan face isolation, exploitation and abuse, with little or no protection from the state. Migrant domestic workers are crucial to the economy in Jordan, contributing to the well-being of the households where they work and providing vital incomes for their own families and communities. Many face exploitation and abuse, working up to 19 hours per day. Wages are meager, and some do not receive payment until years later ${ }^{55}$.

Many workers report being violently treated at the hands of members of their employer's household; they say they are slapped, kicked, beaten, spat at and threatened with violence in the homes in which they work. Several have fallen to their deaths in recent years in circumstances recorded as accidents but which remain inadequately investigated and explained. Around 10 domestic workers are believed to commit suicide every year. Although new safeguards were introduced in 2003 in the form of a special contract for migrant domestic workers; they appear to have had little impact in practice ${ }^{56}$.

Freedom of movement can also be a problem. "At QIZ, a large textile company based in Irbid, the Sri Lankan workers (all women) are not allowed to leave the zone on Fridays (their day off). They complained, and the management made them sign papers stating that they did not wish to leave the workplace on Fridays, although they were asking for the exact opposite. They are only authorized to leave for 2 to 3 hours every three weeks to do some shopping, grouped together in the company bus," denounces Fathalla Omrani, who has brought this affair to the Labour Ministry's attention.

The National Labour Committee (NLC), a US organization for the defense of workers' rights, published a damning 162-page report, based on a one-year study in over 25 factories, detailing the often appalling working conditions of migrant workers in Jordan's export processing zones.

The Jordanian Labour Ministry reacted to this report by taking a series of measures. It has increased the number of work inspectors, has set up hotlines to receive complaints from migrant workers, and has fined a number of employers. At least seven factories have been closed down.

\footnotetext{
53 Ibid p 1-2

54 Mohamed Olwan, “Gender and Migration in Jordan”, CARIM-AS No2010/66, p.6

${ }^{55}$ http://www.amnesty.org/en/news-and-updates/report/isolated-and-abused-women-migrant-domestic-workers-jordan-20081030

${ }^{56}$ Ibid
} 
The number of employers withholding workers' passports has since considerably diminished, as have the cases of exorbitant fees charged by recruitment agencies. The trade unions, for their part, urgently called on the authorities to reform the labour law, to bring it into line with international labour standards, which should apply to Jordanian and migrant workers alike. The government agreed to the GFJTU's demand to permit the establishment of union offices in the industrial zones ${ }^{57}$.

The Ministry of Health is entering into an agreement with the International Organization for Migration (IOM) to conduct medical checkups for migrant workers before they arrive in the Kingdom, a health official said on Tuesday. The cooperation seeks to put an end to the entry of Indonesian workers with infectious diseases into the country, according to Khaled Abu Rumman, director of the ministry's chest diseases directorate. Last year the ministry accredited medical centers in Indonesia to conduct medical checkups for Indonesians coming to work in the Kingdom ${ }^{58}$.

\section{III.C. Recommendations for Elevation of Discrepancies}

Jordan should adhere to ILO conventions no.97 of 1949 and no.143 of 1975 on expatriate workers and International Convention on the Protection of the Rights of all Migrant Workers and members of their Families of 1990, which are largely seen as the seven UN core human rights treaties.

The Jordanian government should enhance coordination among different governmental structures and actors managing immigration; to improve the coherence and transparency of the institutional framework regulating immigration and their issues; and especially to enhance Jordan's humanitarian position towards foreign migrants with the collaboration of international organizations (UN agencies) in order to provide practical solutions.

Migrant workers have little knowledge of trade unions, which they often confuse with the Labour Ministry. They are also unaware of the labour legislation. Given the number of different nationalities, cultures and languages, communication is not easy; all the more so given that many of the migrant workers are illiterate. Jordan should allow migrants to join Unions, and in this way ease their integration into the society, enhance their feeling of belonging, and most importantly to be represented and more involved and participating in the community.

\section{Conclusion}

The last decade has seen an increase in the number of countries experiencing labour migration and a growing tendency for many countries to be both countries of origin and destination. A number of factors suggest that labour migration will be an increasingly important aspect of globalization, posing new challenges and opportunities for policy makers in terms of management of migratory flows.

For many people, the rights provided under international law for an individual to leave and return to his or her country of origin in order to work abroad may be the only basis for a livelihood strategy.

The decision to migrate for economic reasons can have both positive and negative consequences. Migrants may secure a better income, have access to better social services, and be able to provide a better education for their children or benefit from the enrichment of becoming a member of a transnational community at ease in different cultures. However, migration may also cause family disruption when family members have to stay behind, and may involve sacrificing a familiar lifestyle and becoming a "stranger" in a new country.

Labour migration policies differ from other migration policies directed at migration flows that may also have an impact on labour markets, for example refugee and family reunification, in the sense that

\footnotetext{
${ }^{57}$ ITCU, “Migrant workers in the Middle East”, CSI (Confederacion Sindical Internacional), Union view, December 2007

${ }^{58}$ http://www.jordantimes.com/index.php?news=30060
} 
they do not have humanitarian objectives but apply economic criteria with a view to responding to labour market needs. Governments at all points on the migration spectrum increasingly recognize the potential of regulatory mechanisms to maximize the positive impact of labour migration. Many sending and receiving countries are developing their regulatory capacities to manage labour mobility by considering the interests of respective governments.

In brief the majority of non-Jordanians holding a work permit and working in Jordan are young males, poorly educated, working in economic sectors, such as agriculture, construction, and the service sector. They are working in low- level occupations, working too many hours, getting low monthly wages, and face bad working conditions such as residence, health, and mobility.

Citizenship laws in Arab countries make it difficult for non citizens to acquire citizenship no matter how long they have lived in a given country. An Arab woman married to a non-citizen (even if he is an Arab) does not have the right to transmit her citizenship to her children. An Arab husband of an Arab wife is not generally permitted to apply for citizenship for his wife. Birth in the territory of a given country does not automatically confer citizenship either.

This text was largely compiled by Nadine Abdel Khalek under the supervision of the project leaders.

\section{LEBANON}

\section{Towards Effective Temporary Labour Migration Schemes}

\section{The Case of Lebanon}

\section{Introduction}

Lebanon is a dynamic country with respect to its outwards and inwards migration trends. While the former is intertwined with past inter-communal strife and ongoing socio-economic and political crises, the latter is composed of refugees, asylum seekers, and by temporary labour migrants around which this paper revolves. In fact, the country has such schemes with neighboring countries (i.e.: Syria), nonAsian as well as non-African and African countries (i.e.: Egyptian, Syrians, Iraqis, Sudanese, etc.). According to the country migration profile produced by the Consortium for Applied Research on International Migration (CARIM) in January 2010, "Lebanon remains an important destination country for migrant workers”.

Based on Dr. Jureidini’s 2001 paper entitled "Women Migrant Domestic Workers in Lebanon", the following constitutes a decade-old update on the formal realities on temporary migration in Lebanon. This research however does not only focus on migrant domestic workers but on labour migration schemes in Lebanon as a whole. In fact this project has three aims, which are reflected in the three sections of the report. First is to present the various international guidelines, legal instruments and established institutions managing the issue of labour migration. Second is to expose the realities on temporary labour migration schemes in Lebanon. Third is to shed light on the discrepancies between the international provisions and the existing realities in the country, in order to identify gap areas and opportunities for improvement in the future. 
The research was conducted on three stages, the first of which was conducting an extensive literature review of relevant sources from various institutions involved in the study of labour migration. The second stage of this project focused on the creation of a questionnaire based on Jureidini's paper and other relevant references such as the Lebanon country profile published by the Consortium for Applied Research on International Migration (CARIM) in 2010. The third phase concentrated on identifying contact persons and conducting interviews with relevant stakeholders, namely the Lebanese Ministry of Labour, embassies of countries important temporary labour migrants to Lebanon, as well as a number of social partners and members of civil society members.

\section{International Guidelines}

The movements of migration for employment across countries have increased with the increase of the globalization phenomenon as well as the continuous conflicts and deepening poverty of a number of countries of the world. The international community sought to address labour migration and manage its different variables through the action of several institutions. This section outlines the different international players, the various conventions available at the international and regional level, as well as some other players, namely relevant social partners and faith based organizations.

\section{I.A. United Nations Organizations}

The Special Rapporteur of the Commission on Human Rights established the definition of migrants as follows: "all people outside the State of their nationality or citizenship, subject to its legal protection and in the territory of another state; those who do not enjoy the legal status of a refugee, naturalized person or any similar status granted by the hosting state; as well as those whose presence within a hosting state does not fall under the category of diplomatic agreements ${ }^{59}$,.

\section{I.A.1. The International Labour Organization (ILO)}

The International Labour Organization (ILO) is a specialized agency of the United Nations that was established in the aftermath of World War I in 1919 with the aim of addressing labour issues. Its headquarters are in Geneva, Switzerland and its secretariat is known as the International Labour Office. ILO has a tripartite structure that involves governments, employers and workers which constitute the main stakeholders in the management and regulation of labour migration issues dealt with by the organization. The work of the ILO is reflected in its Conventions and its Multilateral Framework on Labour Migration, elaborated upon later in this report.

\section{I.A.2. IOM}

The International Organization for Migration (IOM) is an intergovernmental organization established in 1951 as a framework to resettle displaced people in the aftermath of World War II. IOM is considered the primary intergovernmental organization in the field of migration and focuses on advocating for humane and orderly migration movements as it best serves the migrants and their hosting countries through direct relations with the respective governments. The organization's constitution explicitly acknowledges the close relation between migration and economic, social and cultural development of states, thus it works on promoting international migration laws and policies, and supports governmental, intergovernmental and non-governmental institutions in introducing practical solutions to migration issues as relevant.

\footnotetext{
${ }^{59}$ http://www.unesco.org/new/en/social-and-human-sciences/themes/social-transformations/internationalmigration/glossary/migrant/
} 
The International Organization for Migration defines migration as "a process of moving, either across an international border, or within a State. It is a population movement, encompassing any kind of movement of people, whatever its length, composition and causes; it includes migration of refugees, displaced persons, uprooted people, and economic migrants.” (Glossary on Migration, International Migration Law 2004 paper $^{60}$ ). The International Convention on the Protection of the Rights of all Migrant Workers and Members of their Families ${ }^{61}$ (1990) refers by "migrant" to any "person who is to be engaged, is engaged or has been engaged in a remunerated activity in a State of which he or she is not a national." ${ }^{62}$

\section{I.A.3. The United Nations Educational, Scientific, and Cultural Organization (UNESCO)}

The UNESCO is a specialized agency of the United Nations established in 1945 with the purpose to contribute to peace and security by promoting international collaboration through education, science and culture in order to foster universal respect for justice, the rule of law and the human rights and freedoms provided by the UN Charter. Among its other programs, the UNESCO works on the promotion of cultural diversity and the preservation of human rights.

With respect to migration issues, the UNESCO acknowledges the wide variety of categories for the definition of migration depending on its socio-economic, political and legal determinants relevant to every country. It thus offers a list of common categorizations of international migrants as follows: temporary labor migrants, highly skilled and business migrants, irregular migrants, forced migration, family members and return migrants ${ }^{63}$. The following research revolves around the first concept, i.e.: labour migrant, also referred to as guest workers, overseas contract workers or economic migrants to designate those "people who migrate for a limited period of time in order to take up employment and send money home."

\section{I.B. UN Conventions}

The United Nations has presented a series of international provisions related to the rights of migrant workers in various conventions, some of which are directly addresses to this group (Rights of all Migrant Workers and members of their Families), while others tackle the issue under another theme (Economic, Social and Cultural Rights, Civil and Political Rights, Women’s Rights).

The Universal Declaration of Human Rights adopted in 1948 binds State parties to prevent torture and inhuman treatment of all individuals (Article ${ }^{65} 5$ ), to grant the right to freedom of movement and expatriation to all individuals (Art.13), to allow the free choice of employment and ensure appropriate working conditions (Art.23), and to grant the right to rest and leisure (Art.24).

\section{I.B.1. The International Covenant on Economic, Social and Cultural Rights}

The International Covenant on Economic Social and Cultural Rights (1966) entered into force in 1976 and present relevant provisions to the Rights of workers in Part $\mathrm{III}^{66}$.

\footnotetext{
${ }^{60}$ http://www.iom.int/jahia/webdav/site/myjahiasite/shared/shared/mainsite/published_docs/serial_publications/Glossary_eng.pdf)

${ }^{61}$ http://unesdoc.unesco.org/images/0014/001435/143557e.pdf

62 http://www.unesco.org/most/migration/glossary_migrants.htm

63 Ibib.

${ }^{64}$ Ibid.

${ }^{65}$ For ease of use, Article will be referred to using the abbreviation Art.

${ }^{66}$ http://www.unesco.org/education/information/nfsunesco/pdf/SOCIAL_E.PDF
} 
In fact, the Covenant acknowledges the right of everyone to work as an opportunity to gain decent living by working where one "freely chooses or accepts" (Art.6). It also provides for the right of "all workers, as a minimum" with fair wages and equal compensation for work of equal value "without distinction of any kind" (Art.7). This article also provides for a decent living for workers and their dependants, safe and healthy work conditions as well as "rest, leisure and reasonable limitation of work hours and periodic holidays with pay" (Art.7). Art.9 binds State parties with the obligation to provide social security and insurance while Art.10 provides for paid leaves for working mothers around childbirth.

\section{I.B.2. The International Covenant on Civil and Political Rights}

The International Covenant on Civil and Political Rights ${ }^{67}$ (1966) entered into force in 1976 and provides for the rights of people at work whereby no one shall be held in servitude nor be forced to compulsory labour (Art.8). It also grants all persons the right to gather in trade unions as to advocate for their particular interests (Art.22), and asserts that the provisions of the Covenant do not contradict with the ILO Convention of 1948 (which will be elaborated in paragraph 5 of this section). With regards to freedom of mobility, relevant to our discussion of the rights of migrant workers, the Covenant on Civil and Political Rights grants the right to liberty of movement and the freedom to leave any country to all persons lawfully within the territory of a State (Art.12).

\section{I.B.3. The Convention on the Elimination of all forms of Discrimination Against Women (CEDAW)}

One category of migrant workers that is highly relevant to the following discussion on temporary labour migration schemes in Lebanon is the category of female domestic workers. In this respect, it is of value to examine the Convention of the Elimination of all forms of Discrimination Against Women ${ }^{68}$ (CEDAW). In Part III, Art.11 of the Convention calls for the elimination of discrimination against women at work in order to ensure equal rights to men with regards to work, free choice of employment, remuneration, social security as well as their right to protection of health and to safety in working conditions. Further, Art.15 of part IV binds State parties to accord the same rights to men and women with regards to the law relating to their movement and to their freedom to choose their residence.

\section{I.B.4. The International Convention on the Rights of all Migrant Workers and Members of their Families}

With the increase in the migration movements across countries, the UN has again attempted to act as an international framework that regulates inter-state dynamics in such a way to safeguard the dignity and the rights of the human beings.

The UN Convention on the Protection of the Rights of all Migrant Workers and Members of their Families constitutes an international guideline for the prevention and elimination of all forms of exploitation of migrant workers since the moment of their departure from home country until their return. It encourages efforts to end their illegal, clandestine or undocumented employment or trafficking. It also introduces "a set of binding international standards to address the treatment, welfare and human rights of both documented and undocumented migrants, as well as the obligations and responsibilities on the part of sending and receiving States" (UN Press Release L/T/4371 ${ }^{69}$, Convention on Protection of Rights of Migrants Workers). In addition, the Convention differentiates

\footnotetext{
${ }^{67}$ http://www.hrweb.org/legal/cpr.html

${ }^{68} \mathrm{http}: / /$ www.un.org/womenwatch/daw/cedaw/text/econvention.htm

${ }^{69}$ http://www.un.org/News/Press/docs/2003/LT4371.doc.htm
} 
several groups of migrants to which it applies: those residing in a neighboring country to which they return frequently, seasonal or occasional workers, workers on offshore installations which fall under the jurisdiction of a State other than their own; itinerant workers; migrants employed for a specific project; and self-employed workers.

Furthermore, the Convention imposes certain obligations on State parties to promote "sound, equitable, humane and lawful conditions" for all migrant workers and members of their families. These obligations include developing national policies on migration, exchanging information with other State parties and granting employers, workers and their organizations/offices access to information on relevant laws and regulations, as well as generally assisting migrant workers and their families.

The Convention accounts for the rights of its beneficiaries as human beings, starting with basic freedoms of mobility, adequate life and work conditions, protection against cruel treatment or punishment, forced labour, freedom of thought, religion and opinion, as well as the right to maintain their properties. (Art.1, 9, 10, 11, 12, 13 and 15). It also states provisions for the right of due process of law, in that it enforces established procedures and legal assistance on an equal basis with Nationals of the State of residence, and advocates against arbitrary expatriation (Art.22). The right to privacy (including privacy of communication), respect of honor and reputation of the migrant workers and members of their families is provided for in Art. 14 of the Convention. Equality with the Nationals is reiterated in both Art.27 and 28, with regards to remuneration and conditions of work (overtime, hours of work, holidays, wages, safety, termination of contract, medical care, etc). Art. 32 of the Convention grants migrant workers the right to transfer earnings, savings and belongings at the completion of their employment. It also provides for the right to have free access information providing for their rights in a language they understand. Other rights are also introduced in the benefit of migrant workers such as the right to be temporarily absent as well as provisions for employment contract violations. The latter addresses the right of migrant workers to present their cases before relevant authorities in cases of breach of contract by their employers. They shall be entitled to a fair and public hearing by independent and neutral tribunal established by law, similarly to national cases.

Moreover, the Convention governs the recruitment of migrant workers as per the provisions of Art. 66 , by restricting such operations to public services or bodies of the State in which work activity is going to be conducted; public services or bodies of the State of employment on the basis of agreement between the relevant States; and a body established by virtue of a bilateral or multilateral agreement.

\section{I.B.5. The ILO Conventions}

The International Labour Organization (ILO) has introduced international legal instruments targeting migrant workers issues. On the list are both the Migration for employment Convention $1949^{70}$ followed by its revised recommendations the same year, and the Migrant Workers (Supplementary Provisions) Convention 1975.

\section{I.B.5.a. The Migration for Employment Convention (1949)}

The Migration for Employment Convention ${ }^{71}$ stresses on State signatories to provide the ILO as well as the migrant workers with information relevant to national laws, rules and regulations governing their status and realities within the respective countries (Art.1, 2). It also invites member states to facilitate the migration process of workers and ensuring medical care and hygienic conditions in all its phases (Art.4, 5). The Convention also calls for signatories to provide migrant workers equal treatment than that provided to the Nationals, without any form of discrimination with regards to due process, remunerations, membership of trade unions, accommodation, and social security with some

\footnotetext{
${ }^{70}$ http://www.ilo.org/ilolex/cgi-lex/convde.pl?C097

${ }^{71}$ http://www.ilo.org/ilolex/cgi-lex/convde.pl?C097
} 
restrictions, and taxes (Art. 6). Art.8 forbids the forced departure of a permanent migrant worker or any of the dependants is case of the inability to work for health reasons. Migrant workers are entitled to the right to transfer earnings and savings within limits allowed by domestic regulations (Art.9). The convention also encourages bilateral agreements between states importing and exporting "sufficiently large" numbers of migrant workers (Art.10). The Convention however, excludes the categories added by the Special Rapporteur in the UN Convention i.e.: frontier workers, short-term entry members of liberal professions and artists as well as seamen.

The Convention is accompanied by three annexes ${ }^{72}$, which are as relevant as the text of the convention itself. They tackle the issues of recruitment, placing and conditions of labour of "migrants

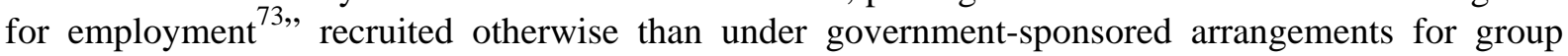
transfer (Anx.I); the recruitment, placing and conditions of labour of migrants for employment recruited under government-sponsored arrangements for group transfer (Anx.II); and the importation of the personal effects, tools and equipment of migrants for employment (Anx.III).

\section{I.B.5.b. The Migrant Workers Convention (1975)}

The Migrant Workers Convention ${ }^{74}$ focuses of two themes, which are migrants in abusive conditions, an equality of opportunity and treatment.

The first part of the Convention deals with the first theme and encourages member states to endorse regulations condemning illegal employment and labour trafficking that comes in contradiction with bilateral, multilateral, or national laws, and ensures no clandestine migration is allowed under its jurisprudence (Art.2, 3, 5). Information shall be exchanged on such instances between states in consultation with the representatives of employers and workers' organizations (Art.4). The Convention also encourages member states to develop national laws to detect such legal discrepancies and to consult with organizations of workers and employers for these aims (Art. 6, 7). It calls upon states not to withdraw work permits or authorizations of residency from migrant workers whose term of employment ended, while providing them with the equal opportunity with nations to secure employment or alternative employment, and relief of work and retraining. Under this convention, member states shall grant migrant workers the right to present their case before competent legal authorities in case of dispute; the fees from potentially resulting expulsion shall not be paid by the worker. Further, the convention does not withhold the right for a state to grant legal status for illegal migrant as to restitute their status within their territory (Art.10).

The second part of the Convention welcomes the efforts of member states to seek cooperation of employers and workers' organizations and other relevant institutions to promote the implementation of the provisions of this convention by enacting adequate legislation and necessary educational programs. Such efforts shall be aiming to familiarize the workers with the enacted policies, while seeking to reform contradictory provision in existing rules and practices. Efforts in the area of policy formulation shall ensure social policies that are both relevant to domestic environment and equally beneficial for national and migrant labour. Equality of treatment shall be enforces as to ensure social integration while preserving the mother culture (right to practice mother tongue for instance) (Art.12). Member states are granted the opportunity to facilitate family reunions among migrant workers and family members under appropriate legal conditions (Art.13). The convention grants migrant workers the free choice of employment, while ensuring the lawful right to mobility for a period not exceeding two years or less if so mentioned in the work contract. While the state is called to make regulations concerning certificates and diplomas reflecting occupational qualifications of migrant workers, it could restrict access to certain positions if it is in the interest of the State (Art.14).

\footnotetext{
${ }^{72}$ For ease of use, Annex will be referred to using the abbreviation Anx.

73 Another term designating "migrant workers"

${ }^{74}$ http://www.ilo.org/ilolex/cgi-lex/convde.pl?C143
} 


\section{I.B.5.c. The ILO Multilateral Framework on Labour Migration (2006)}

Moreover, the ILO published in 2006 its "Multilateral Framework on Labour Migration: Non-binding principles and guidelines for a rights-base approach to labour migration"75. The framework aims to address the major issues raised by the labour migration phenomenon at the national, regional and international levels. It draws practical guidelines and provides best practices in line with the existing international provisions in order to address the important theme of decent work for all, regulatory policies to relate human rights and development to labour migration. This multilateral framework constitutes a nonbinding context which respects the states' sovereignty in developing national migration policies, celebrates the important role of social partners and encourages gender-sensitive migration policies (Ibid).

The themes addressed in the framework are decent work for all workers including migrant workers through the introduction of adequate national policies. It encourages the means for international cooperation on labour migration through intergovernmental dialogue, bilateral and multilateral agreements and the exchange of information between relevant parties. The framework also provides guidelines for the creation and maintenance of a global knowledge base through the establishment of mechanisms to collect migration data and its exchange among states in order to create a tool for best practices. Guidelines for effective management of labour migration include the development of comprehensive migration strategies that reflect domestic regional and international efforts to protect the rights of migrant workers. This particular issue is also accompanied with recommendations revolving around the compatibility between national laws and the international provisions pertaining to human rights in general and the rights of migrant workers in specific. The framework also offers guidelines for the prevention of and protection against abusive migration practices, not only through the formulation of strict legislation in this regard but also through a fair sanctions system that enforces protective legislations. Guidelines for an adequate migration process are also presented, as to ensure the rights of migrants at all levels of their journey (from departure to repatriation). ILO also addressed the issue of social integration and inclusion of migrant workers through the promotion and the implementation of non-discriminatory legislation and the enhanced cooperation between the various parties (governments, employers associations and labour unions). Finally, the framework tackles the issue of migration and development, and encourages the revision of remittance policies (Ibid).

Best practices annexed to the framework will be regularly updated to maintain an up to date database of best practices and lessons learned.

\section{I.B.5.d. Other conventions}

Although less relevant to the issue at hand, there are two additional conventions that "are relevant to the protection of migrant workers: C105 Abolition of Forced Labour Convention (1957) and C111 Discrimination (Employment and Occupation) Convention (1958).

\section{I.C. Regional Level - Arab Human Rights Agreements}

\section{I.C.1. The Arab Charter on Human Rigths (2004)}

The Arab Charter on Human Rights addresses, inter alia, economic, social and cultural issues relevant to Arab States ${ }^{76}$. The Charter provides for the right to work (Art. 34); the right to form trade unions (Art. 35); the right to social protection (Art. 36); the right of development (Art.37); the right of

\footnotetext{
${ }^{75}$ http://www.ilo.org/public/english/protection/migrant/download/multilat_fwk_en.pdf

${ }^{76}$ http://en.wikipedia.org/wiki/Arab_Charter_on_Human_Rights
} 
education (Art. 41); the right to participate in cultural life (Art. 42) ${ }^{77}$. In addition, Art.10 of the Charter bans "slavery and slave trade in all their forms" and calls upon penalties when violations of this particular right occur. Further. It prohibits all forms of slavery and servitude, as well as forced labour, human trafficking for prostitution or sexual abuse, namely affecting children in armed conflict.

\section{I.C.2. The Arab Declaration on International Migration}

The Arab Declaration on International Migration ${ }^{78}$ is considered a tool to activate the role of migration in national development and Arab regional integration. The Declaration acknowledges that "addressing migration issues and their implications requires a holistic approach linking immigration to development, partnership and cooperation dimensions to tackle the structural causes of intense migration, including poverty, discrimination and disparities in rates of welfare, economic growth and political and social stability among nations:. In an attempt to join the global effort towards regulating the process of labour migration in its various aspects, the Declaration:

"urges [in Art.6] all labour-receiving States to enhance human rights and fundamental freedoms o all immigrants, to protect migrants' rights against illegitimate actions or acts of violence, particularly those of racial discrimination and crimes committed by individuals and groups motivated by racism or xenophobia.",79

\section{I.C.3. The Cairo Declaration on Human Rights in Islam (1990)}

The Cairo Declaration on Human Rights in Islam is also relevant as it calls upon the State and the Society to celebrate the right of each individual to work ${ }^{80}$.

Art.13 states that "everyone shall be free to choose the work that suits him best and which serves his interests as well as those of the society." Art.13 also grants employees the right to work in a safe and secure environment regulated by social guarantees; "he may not be assigned work beyond his capacity nor shall he be subjected to compulsion or exploited or harmed in any way." ${ }^{\text {"T1 }}$ The Declaration prohibits all forms of discrimination between males and females in respect to equal pay, and provides for holidays and leisure time. The Declaration further addresses the obligations of employees in terms of their dedication to work, and allocates the responsibility of settling labour dispute to the State ${ }^{82}$.

\section{I.D. Social Partners: Trade unions, Employers Organizations, and Labour Unions:}

According to the ILO terminology, the Social Dialogue includes all types of negotiation, consultation or simply exchange of information between key representatives of governments, trade unions/employers' organizations and workers in a tripartite setting ${ }^{83}$. While it is extremely important to

\footnotetext{
${ }^{77}$ http://www.acihl.org/res/Arab_Charter_on_Human_Rights_2004.pdf

${ }^{78}$ Retrieved online at <http://www.poplas.org/upload/mig_dec_en.pdf>

${ }^{79}$ Ibid

${ }^{80}$ Cairo Declaration on Human Rights in Islam,Aug. 5, 1990, U.N. GAOR, World Conf. on Hum. Rts., 4th Sess., Agenda Item 5, U.N. Doc. A/CONF.157/PC/62/Add.18 (1993) [English translation].

${ }^{81}$ Ibid

${ }^{82}$ Retrieved online at <http://en.wikipedia.org/wiki/Cairo_Declaration_on_Human_Rights_in_Islam> and http://www1.umn.edu/humanrts/instree/cairodeclaration.html> on 27 January 2011.

83 Ishikawa, J. (2003). Key features of national social dialogue: A social dialogue resource book. Retrieved from ILO, Dialogue Industrial and Employment Relations department website, retrieved online at http://www.ilo.int/public/english/dialogue/ifpdial/downloads/papers/key.pdf
} 
acknowledge and stress the primary role that States $^{84}$ are called to play through abiding their obligations to set the international and national framework of protection for migrant workers' rights, it is also important to examine the role that social partners play in shaping labour migration policies.

\section{I.D.1. Labour Unions:}

Labour unions play a significant role ${ }^{85}$ in this perspective. However, their role has progress in time whereby they used to exhibit some reluctance to engage with migrant workers because of competition reasons ${ }^{86}$. They now realized the importance of including migrant workers as part of their endeavors ${ }^{87}$, and have subsequently introduced a proactive agenda focusing on addressing the needs of migrant workers with regards to the gender dimensions as well ${ }^{88}$. This agenda addresses the following fronts: organizing migrants (including undocumented migrants), campaigning for migrant workers' rights and the ratification and application of UN and ILO conventions on migrant workers, combating widespread racism, discrimination and xenophobia against migrant workers. Trade unions have established a consultative process to facilitate common policy positions and practical inter-union cooperation.

\section{I.D.1.a. The International Trade Union Confederation:}

An important instance of such is the new International Trade Union Confederation (ITUC) uniting the member federations of the International Confederation of Free Trade Unions and the World Confederation of Labour into a single global body that represents most of the world's organized workers ${ }^{89}$. The ITUC is the world's largest international trade union body, which applies the nonbinding international norms set by the ILO multilateral framework. It also conducts campaigns advocating the ratification of the ILO conventions 97 and 143 resolution on a fair migration policy. The ITUC mobilizes against racism and xenophobia, for the UN to take responsibility for migration, and for policy based on labour standards and other human rights. As far as temporary labour migration is concerned, the ITUC acknowledges the need to reconsider the assumption that the promotion of temporary labour migration programs as a solution to both labour shortages in destination countries and development deficits in countries of origin. In fact, "in many cases these simplistic assumptions have proved wrong and the guest workers programs agreed by sending and receiving countries during Global Forums on Migration and Development are increasingly used as a way to circumvent labour laws and standards," says Sharan Burrow the ITUC general secretary. Advocacy and services addressing migrant issues remains one of the ITUC's main thematic priorities. It is important to mention at this stage that Lebanon is not a member of the ITUC.

\section{I.D.1.b. The World Federation of Trade Unions (WFTU):}

The WFTU also takes part of the global efforts to push forward its international agenda through developing working partnerships with various national and industrial trade unions across the world. It

\footnotetext{
${ }^{84}$ Meetings Coverage and Press Releases, United Nations. (2003, March 19). Convention on protection of rights of migrant workers to enter into force next July [Press Release]. retrieved online at http://www.un.org/News/Press/docs/2003/LT4371.doc.htm

85 Añonuevo, T. (2007). The Role of the Trade Union Movement in Migration and Development: A Contribution from the Building and Wood Workers International (BWI). International dialogue on migration intersessional workshop on making global labour mobility a catalyst for development. Geneva: IOM

${ }^{86}$ Abella, M. (2006). Policies and best practices for management of temporary migration. International symposium on international migration and development. Turin: United Nations

${ }^{87}$ Retrieved online on the ICFTU website at http://www.icftu.org/

${ }^{88}$ Chammartin Moreno-Fontes, G. (2008). Migration, gender equality and development. International Conference on Gender, Migration and Development: Seizing Opportunities, Upholding Rights Manila: ILO

${ }^{89}$ Retrieved online from ITUC website at <http://www.ituc-csi.org/>
} 
also seeks partnerships with a number of international and regional trade union organizations including the Organization of African Trade Unions Unity (OATUU) and the International Confederation of Arab Trade Unions (ICATU) ${ }^{90}$. The WFTU took part of the $53^{\text {rd }}$ Session of the UN Commission on the Status of Women (2009). "In many countries violence against women is on the rise, prostitution is spreading, economic migration is separating many mothers from their children and deprives them of the right to education, to cultural activity, to free time."91

Other examples of the increased international collaboration for the regulation of migrant workers' issues include the sectoral global union federations focalizing on irregular-status migrants i.e. the Public Services International, the International Union of Food and Agricultural Workers (IUF) and the International Federation of Building and Wood Workers (IFBWW ${ }^{92}$. Further, on a regional level, the International Confederation of Arab Trade Unions (ICATU) also takes part of this global effort by working towards its fundamental objective to "guarantee the rights of Arab migrant workers in the Arab countries. ${ }^{93,}$

\section{I.D.1.c. Joint ILO Bureau for Workers’ Activities/Lebanese Minister of Labour Initiative}

Furthermore, on November 11 and 12, 2010, a Workshop on the Role of Trade Unions in Promoting Decent Work for Domestic Workers in Arab Countries that was held in Beirut. The workshop joined representatives of trade unions in Arab countries and resulted in the unanimous adoption of the Statement of Trade Unions in Arab Countries promoting decent work for Domestic Workers ${ }^{94}$. The workshop was organized by the ILO Regional Office for Arab States and the ILO Bureau for Workers' Activities, and opened by Lebanese Minister of Labour Boutros Harb. It was created as a forum aiming to "enable Arab trade unions to contribute to the setting of international labour standards and to formulate a regional position in support of a landmark international treaty on decent work for domestic workers. ${ }^{95}$,

Participants in the workshop committed to promote decent work for all, including domestic workers, and assured that they will follow-up on the Statement in their respective countries, as well as the regional and international levels. In this perspective, they reassured their full support to the position of the Workers' Group for the adoption of an International Convention on Decent Work for Domestic Workers accompanied by a Recommendation, as well as the establishment and enforcement of domestic policies eliminating any form of discrimination against, and recognizing the rights of domestic workers.

The Statement revolves around the reassurance of the participants that domestic work is real work, and thus domestic workers shall enjoy equal opportunities, rights and legal protection offered to all other workers. It reiterates the trade unions' and freedoms including ILO Conventions No.87 and 98 providing all workers the "right to organize themselves into unions", engage in collective bargaining and be involved in issues relating to them. The participants suggested that the upcoming Convention and Recommendation shall pertain to all domestic workers without exceptions. The Statement also emphasized the urgent need to eliminate all forms of discrimination against domestic workers, based on gender, nationality, religion, color, race or belief. It also praises the right of domestic workers to written and fair terms of employments, decent and safe working and living conditions, fair wages, social security, health care, and respect for privacy. The Statement also stresses the importance of the

\footnotetext{
${ }^{90}$ Retrieved online at http://en.wikipedia.org/wiki/World_Federation_of_Trade_Unions on 28 February 2011

${ }^{91}$ Retrieved online at <http://www.wftucentral.org/?p=2576\&language=en> on 28 February 2011

92 IUF. 2008). Workers and unions on the move: Organising and defending migrant workers in agriculture and allied sectors. Retrieved online at <http://www.iufdocuments.org/www/documents/IUFmigrantworkersmanual-e.pdf>

93 Translated from: http://www.icatu56.org

94 http://www.ilo.org/sapfl/News/lang--en/WCMS_146786/index.htm

95 Ibid
} 
ratification of the Private Employment Agencies Convention (1997) which calls for the effective protection of domestic workers against all forms of abuse. The participants finally agreed to forbid the employment of children below minimum admissible age, and to provide domestic workers with the access to legal authorities in case of trials.

The participants will be presenting their views reflected in the Statement to the ILO, in preparation for the second discussion in June 2011.

\section{I.D.2. Employers’ Organizations:}

As far as employers' organizations are concerned, the main player within the employers' organizations community is the International Organization of Employers (IOE) whereby migration constitutes one of its policy areas. Operating as secretariat for the "Employer's group" at the ILO, the IOE has participated in the drafting of the ILO Multilateral Framework on Labour Migration, worked closely with the Global Commission on International Migration and currently track through the World Trade Organization (WTO) consultative process, the liberalization of cross border movement of professional, managerial and technical personnel ${ }^{96}$."

\section{I.E. Global Civil Society}

The global civil society constitutes an overarching body, which generally imposes its moral authority over states and other players managing labour migration issues. It is involved in defining the migration agenda and developing its content and ensuring that the migration agenda reflects existing international legal standards protecting migrants. It also works in lobbying for key principles pertaining to the regulation of labour migration issues, providing timely and reliable information on existing realities and practices and progress towards reforms, and monitoring the implementation of states' obligations vis-à-vis international binding provisions ${ }^{97}$.

Examples of global civil society actors based on the members of the International NGO Platform on the Migrant Workers Conventions (IPMWC) comprise two categories of civil actors: secular and faith-based players ${ }^{98}$. The former includes, inter alia, Anti-Slavery International; Human Rights Watch; the International Centre for Migration, Health and Development (ICMHD); the International Movement Against All Forms of Discrimination and Racism, Migrants Rights International, and Amnesty International. The latter contains the International World Council of Church (IWCC), the International Catholic Migration Commission and Caritas Migrants, among others.

While the secular civil society actors approach the issue of labour migration from a pragmatic, socio-economic, policy and human rights based approaches based on international provisions on the rights of migrants, the faith-based organizations inspired by the Church's view on this phenomenon. Examples of such include the Papal Encyclical Exsul Familia Nazarethana ${ }^{99}$ of Pius XII (1952) and the Encyclical letter Caritas in Veritate ${ }^{100}$ of the Supreme Pontiff Benedict XVI (2009).

96 Retrieved online on February 27, 2011 on the IOE website at <http://www.ioe-emp.org/en/policyareas/migration/index.html

97 Collet, L. (2008). The Civil Society Day of the Global Forum on Migration and Development. (Report No. D/2007/2893/52) Retrieved online at

http://www.kbsfrb.be/uploadedFiles/KBSFRB/05)_Pictures,_documents_and_external_sites/09)_Publications/EndReport Migration\&Dev.pdf

${ }^{98}$ Retrieved online at <http://www.december18.net/international-ngo-platform-migrant-workers-convention-ipmwc>

${ }^{99}$ Retrieved online at <http://www.papalencyclicals.net/Pius12/p12exsul.htm>

${ }^{100}$ Retrieved online at <http://www.vatican.va/holy_father/benedict_xvi/encyclicals/documents/hf_benxvi_enc_20090629_caritas-in-veritate_en.html> 
The first is a twofold document that addresses the Church's motherly solicitude for migrants in its first part and the Spiritual care of migrants in the second. The latter focuses on the competency of the consistorial congregation regarding migrants, the Delegate for migration affairs, directors, missionaries to migrants and Ship Chaplains, the spiritual care local ordinaries are to provide aliens, the spiritual care to be provided migrants by Italian bishops and the pontifical college of priests at the service of Italian Migrants.

The second addresses the issue of migrants in its fifth chapter (paragraph 62) with regards to the cooperation of the Human family, of which migration is an aspect. The letter acknowledges the difficulty to manage migration regarding its various determinants, and encourages states to collaborate to better address the issue's complexities.

"Policies should set out from close collaboration between the migrants' countries of origin and their countries of destination; it should be accompanied by adequate international norms able to coordinate different legislative systems with a view to safeguarding the needs and rights of individual migrants and their families, and at the same time, those of the host countries."

The letter also celebrates the significant role that migrants play in enhancing the economic status of their home and host countries, and directs the attention towards maintaining the respects towards them as human beings:

"these labourers cannot be considered as a commodity or a mere workforce. They must not, therefore, be treated like any other factor of production. Every migrant is a human person who, as such, possesses fundamental, inalienable rights that must be respected by everyone and in every circumstance."

\section{Formal Reality on Lebanon}

This section provides an overview of the existing realities and practices with respect to temporary migrant workers in Lebanon. Data supporting this section was made available through reviewing of the literature relevant to migrant labour in Lebanon, including studies, policy documents and civil society reports on the status of Migrant Domestic Workers (MWDs). In addition to the desk research, a number of interviews was conducted with key players representing government, legal, NGO and embassy representatives, aiming to gather more essence data which literature fails to provide. Nonetheless, the original research also presents its limitations which will be elaborated upon throughout the following section.

\section{II.A. Lebanese Government Level}

\section{II.A.1. Laws, regulations, formal policies}

Despite the richness of the country in temporary migrant workers schemes, regulatory frameworks remain poor and tailored based on the continuously changing governmental policies. CARIM Lebanon's profile ${ }^{101}$ informs that the country: "has come under fire in the last decade for undermining immigrant rights (migrant workers and refugees)".

In fact, the Lebanese legislative texts pertaining to the entry and exit of foreign nationals as well as to the access to nationality go back to the 1960s (1962 and a 1960 amendment to the 1925 regulation respectively). Both issues have been kept pending political discussion and executive action due to their sensitivity and their potential effects on the fragile stability of the multi-confessional state (Ibid).

\footnotetext{
101 http://www.carim.org/public/migrationprofiles/MP_Lebanon_EN.pdf
} 
The Law ${ }^{102}$ relative to the entry of foreigners into Lebanon, their stay and their exit from Lebanon, issued on July 10, 1962, requires the approval of the Ministry of Labour and Social Affairs prior to foreigners' entry for employment. It also provides for the freedom of mobility of all foreigners legally resident in Lebanon with restrictions if any. It specifies one-entry or multiple-entry authorizations for a six-month period, extendable to one year, while the residency card is issued for one year, extendable for three years. Foreigners shall be deported in case the Lebanese authorities consider them as a danger to national security. The law also provides for penalties on illegal entries while it grants a twomonth grace period to legalize residence.

The implementation of the above-mentioned Law is addressed in two additional legislative documents: the legislative decree ${ }^{103}$ No.10188 of 28 July 1962 as well as the Minister of the Interior's Decision $n^{\circ} 320,2$ August 1962, on the control of entry and exit from Lebanese border posts ${ }^{104}$. General provisions for entry/exit and circulation of foreigners in Lebanon include no visa requirements for Jordanians and the Gulf Cooperation Council.

\begin{abstract}
"A free one-month visa is issued at airports and frontier posts to nationals from 80 non-Arab countries and only at airports to nationals from 11 Arab states and 3 African states. 6 to 11 months visas are delivered to some categories of foreign nationals (company leader, investors, etc). Workers Entry submitted to an authorization of the Ministry of Labour and of the General Security Direction. List of countries whose nationals have easier access to Lebanon. Women from Indonesia, Guinea and Sierra Leone are not allowed to work as servants. Artists' entry is submitted to General Security Direction authorization. Syrian nationals enter with their identity card.” (CARIM, Lebanon Country Migration Profile 2010).
\end{abstract}

In the more specific case of Migrant Domestic Workers (MDWs), the Lebanese Labour Code of 1964 equally excludes Lebanese and migrant domestic workers from its terms. This implicates that domestic workers do not enjoy the basic rights of other types of workers such as minimum wage, maximum daily working hours, fair rest and leaves etc... This leaves the migrant domestic workers under the mercy of contractual arrangement, if such exist, generally administered between the employer and the worker.

Lebanon has been pressured by international organizations, concerned embassies and other players to introduce reform to its labour laws, and more specifically to the legal provisions governing migrant labour. Jureidini outlines five measures through which the Lebanese government attempted to introduce reform in this area. The first measure was banning the process of "releasing" a foreign worker from one Kafeel to the other in 1998. The second introduced a scheme of tax costing around $24 \$$ for the pre-registration visa and thus reducing the original cost of $250 \$$. The third step was to establish a complaint procedure while the forth consisted of computerizing the names of all incoming Lebanon as well as their addresses. The fifth measure was the issuance of an amnesty from 2000 till 2001 providing that all illegal residents in Lebanon can apply for residency or depart the country.

In 2005, General Security signed an agreement with Caritas on the issue of human trafficking, providing for a "house of security". Existing records and literature account for the establishment of this "safe house" without providing an assessment of its value. In this respect, interviews conducted with key players gave us insight that is more critical on the issue. In fact, Maitre Hasna Reda lawyer and activist, took an opponent stand vis-à-vis the concept of a safe house as a place where migrants are "locked inside" and "cannot go anywhere" with "no access to the outside" 105 . Simel Esim, gender and women workers' specialist in the ILO Regional Office for Arab States, presented a more optimistic opinion. She believes that what Caritas and the General Security offer is the only solution for abused

\footnotetext{
102 http://www.carim.org/public/legaltexts/LEB00241.pdf

103 http://www.carim.org/public/legaltexts/LEB00242.pdf

104 http://www.carim.org/public/legaltexts/LEB00243.pdf

${ }^{105}$ Interview with Maitre Hasna Reda, 17 January 2011.
} 
migrants. The government and Caritas have no other benchmark to compare their experience to and thus the safe house is the only module in Lebanon for protecting migrants from being abused further"106. It is a government agency, not an NGO, thus the high level of security aiming to protect migrants and ensure the secrecy of their situation. In addition, the rather limited experience of the Lebanese government experience in this sector highly correlates with a misuse of authority leading to a general perception that the house is rather a prison.

In 2007, Lebanon signed the International Convention on Labour Law, and the newly collapsed cabinet had been working on a draft for a draft of a new labour law. The hopes of the migrant workers might have collapsed, as have those of the Lebanese in entrusting the government to deliver needed services to both local and foreign constituencies.

With respect to the terms and conditions of employment, there is for instance an accreditation procedure to license recruitment agencies wishing to procure Filipinas for work in Lebanon. Licensed agencies are required to use the Embassy's "Master Employment Contract for Domestic Helpers" which stipulates the terms and conditions of employment (in English and Arabic).

In 2009, the Lebanese Ministry of Labour introduced a compulsory unified contract clarifying certain areas and terms of recruitment for MDWs) which according to the Human Rights Watch constitutes:

"A step forwards in protecting MDWs because it outlines the responsibility of the employer to: pay the full salary on a monthly basis with receipts of payment; provide a 24-hour rest period each week and paid sick leave; buy health insurance for employees, and allow workers to correspond with their family. It also restricts the maximum number of daily working hours, and prevents employers from compelling MDWs to work in more than one house." (Human Rights Watch 2010 report $)^{107}$

Unfortunately, the newly standardized contract is neither ideal in content nor in practice. On the one hand, it maintains the right of the MDW to leave the house pending the approval of the employer; it also does not forbid the employer from taking possession of the MDW's passport. Further, it explicitly favors the employer in cases of breaching the contract thus making the MDW's position even more vulnerable. In fact Articles 16 and 17 of the contract reflect this favoritism in that the former provides for wide opportunities to the employer to terminate the contract while it narrows as much as possible those of the worker to do so. On the other hand, the contract lacks a proper mechanism which ensures the proper implementation of the contract and a penalty system which records violations and acts upon them.

Early in 2010, the Minister of Labour Boutros Harb established a hotline aiming to receive the complaints of MDWs pertaining to violations of their rights by their employers. Until July 2010, no complaint has yet been placed on the hotline, probably due to the narrow dissemination of information pertaining to this hotline ${ }^{108}$.

The reforms that the Lebanese government has so far undertaken with relation to temporary migrant workers have been very slow and generally not in perfect synchrony with advised international guidelines. In fact, while international UN conventions call upon a culture of respect to diversity and the primacy of the human dignity, national Lebanese legislation fails to provide for the minimal basic rights of protection against discrimination in the area of employment, abuse such as maltreatment, violence and forced labour, as well as arbitrary detention and deportation.

\footnotetext{
106 Interview with Simel Esim \& Gudrun Jevne - Gender and Women workers' specialist / ILO Regional Office For Arab States, January 18, 2011

107 http://www.hrw.org/en/reports/2010/09/16/without-protection?print

${ }^{108}$ Interview with Mr. Ziad Sayegh, Team Leader of the Ministry of Labor and Policy Advisor, 17 January 2011
} 


\title{
II.A.2. National Institutions and Responsible Authorities
}

The key governmental agencies managing the issue of migrant labour are the Ministry of Interior (also General Security) Ministry of Labour and the Ministry of Social Affairs. These three bodies implement the national strategy for inward migration, which revolves around the following principles:

\begin{abstract}
"Regulate immigration with regard to the admission, residency and work permits of foreign nationals and migrant workers; developing actions with international organizations so as to mitigate irregular and transit immigration; reduce the number of undocumented workers by apprehending, regularizing and deportation procedures; identify refugees; devise action plans with regard to their presence and stay in Lebanon or with regard to their resettlement; coordinate with international organizations in respect to Palestinian and Iraqi refugees” (Ibid).
\end{abstract}

\section{II.A.3. Specific references to ratification of international guidelines, and bilateral agreements}

Lebanon is a founding member of the UN charter. It is bound by the United Nations Declaration of Human Rights and has so far ratified the Covenant on Political and Civil Rights, as well as the Covenant on Economic, Social and Cultural Rights in 1972. It has ratified CEDAW in 1997 with reservations which have raised doubts (namely from the Republic of Denmark) on the commitment of Lebanon to the full implementation of the Convention. Further, Lebanon is yet to ratify the 1990 Convention on the Protection of the Rights of all Migrant Workers and Members of their Families.

Of the ILO conventions outlined in section I.B.5., Lebanon is only bound by the Universal Declaration of Human Rights, Convention 105 on the Abolition of Forced Labour and Convention 111 on the Discrimination in Respect to employment and Occupation, which were ratified in 1948, 1977 and 1977 respectively. Lebanon has not yet ratified the ILO conventions of 1949 and 1955, although it has adopted 14 ILO conventions on International Labour Standards.

In general, the Lebanese authorities are reluctant to ratify international agreements, even basic ones such as the 1951 Geneva Convention and the 1990 Convention. Reluctance of the Lebanese state is due to the sensitivity of their repercussions as well as the uncertain ability of the relevant governmental agencies to implement and enforce their provisions.

With respect to bilateral agreements between the government of Lebanon and country of migration, neither Sri Lanka nor the Philippines has signed a bilateral agreement with the Ministry of Labour pertaining to the rights and working conditions of their constituencies in Lebanon ${ }^{109}$. It is possible however that the latter had in fact signed a bilateral agreement in the past, yet ruled it out after an incident of death of one of the Filipino domestic workers. According to Maitre Hasna Reda ${ }^{110}$, the Lebanese government has so far only established a bilateral agreement with Egypt; she added that work agreements with Ethiopian, Filipino, Indian (among other) economic migrants are established between the employment office and the relevant embassies. Further, representatives of Indyact ${ }^{111}$ informed us that the Philippines and Ethiopia bands their citizens to come to Lebanon after the many abuses reported. According to them,

"Lebanon did sign a bilateral agreement with Ethiopia and Philippines; however, due to work conditions in Lebanon and due to widespread racism against the workers, abuse and huge number of death (ranging from one to two incidents per week according to the Human Rights Watch report (2008)), these countries band their citizens to come Lebanon. Therefore, migrant workers travel to another country in order to get to Lebanon”.

\footnotetext{
109 Interview with the Ambassador of the Philippines in Lebanon and the Counsular of Sri Lanka WM Premarathna, conducted respectively on 12 and 17 January 2011.

${ }^{110}$ Interview with Maitre Hasna Reda, 17 January 2011.

${ }^{111}$ Interveiw with Farah Salka and Ali Fakhry, Indyact representatives, 20 January 2011. Indyact is a global non-profit organization based in Beirut.
} 
On another hand however, the ILO mentioned some pending bilateral agreements with Ethiopia and Sri Lanka ${ }^{112}$

\section{II.B. Lebanese Social Partners}

The Lebanese Social partners play as important a role as the governmental authorities do in managing labour migration issues in the country. Research on this area mainly focuses on the recruitment agencies of the migrant domestic workers. We will however attempt to provide a more inclusive overview on other players, namely with respect to employers organizations.

\section{II.B.1. Employers’ organizations}

Employers' organizations are generally the most benefiting from migrant labour. In fact, according to the PCAAM 2010 report, contracts are made by the recruiting agencies and put the salary at 100 USD or 125 USD. Salaries may vary for instance Indian labourers in Lebanon earn a monthly average of 225 USD while Filipina domestic workers frequently receive higher wages because they tend to be more educated and speak fluent English ${ }^{113}$; however, compensation for migrant workers unskilled services has barely reached thus rarely exceeded the minimum wage set by the Lebanese Labour Law. Values as such may be negotiated between the agency and the employer without neither the consultation nor the signature of the employee in question. Some agents set skyrocketing fees such as 3500 USD for Filipinas, 1500 to 2000 USD for Sri Lankan or Malaysian, in such a way that the client tends to reduce the monthly salary of the domestic worker under the assumption of having already invested too much money at the recruitment stage. Furthermore, employing organizations have the general tradition of requiring the first three to four months' salaries from the domestic worker and end up earning more than the remittances resulting from the overall employment period ${ }^{114}$. Other sources we have interviewed (i.e. Maitre Hasna Reda and Ms. Lina Hawi ${ }^{115}$ ) mentioned that this happens only during the first month of employment.

As far as mobility and freedom to change jobs is concerned, findings from the various interviews with the migrant workers embassies have shown that their constituencies have very restricted movement within the Lebanese territory. This is mainly due to the long working hours as well as the lack of organized unions for the migrant workers namely the domestic workers. In fact, according to representatives from Kafa ${ }^{116}$ (Enough), a Lebanese non-profit, non-political, non-confessional civil society organization established in 2005 by a group of multi-disciplinary professionals and human rights activists, "migrant workers in Lebanon cannot join a trade union or organize collectively to demand for better working conditions. However, a number of migrant communities informally organize through associations. KAFA encourages these associations and works with migrant community leaders to understand the needs of migrant communities and to consult on advocacy and awareness raising activities”.

\footnotetext{
112 L’Ethiopie pour un protocole réglementant le travail des employés de maison, L’Orient Le Jour, 5 October 2010

113 Gloria Moreno- Fontes Chammartin,

2005 Domestic Workers: Little Protection: for the Underpaid. International Labour Organizationn

http://www.migrationinformation.org/Feature/display.cfm?id=300

${ }^{114}$ Martin J. Mc Dermott, Report of the Committee on Pastoral Care of Afro-Asian Migrant (PCAAM) workers in Lebanon to its president Bishop Elias Nassar, Beirut, July 13, 2010, pp. 6

${ }^{115}$ Representative of Le Marin, a domestic workers recruitment agency in Hadath.

116 "KAFA's mission is to work towards eradicating all forms of gender-based violence and exploitation of women and children through advocating for legal reform and change of policies and practices, influencing public opinion, and empowering women and children”, retrieved online at < http://www.kafa.org.lb/>
} 
At this stage, it is worth addressing the important role of migrant networks in channeling migration of workers to Lebanon. In fact, not only do recruitment agents play a role in "importing" migrant workers to the country, but also fellow migrant workers do as well. Friends and/or relatives already working in the country encourage workers to migrate to Lebanon, facilitate their migration process, accommodate them at times and earn commissions within the process.

\begin{abstract}
"Already employed Tamil migrants in Lebanon manage to obtain from their employers the required visas at a price for the person recommended by him at a much lower than those charged by employers from the recruiting agents. These Indian contacts made money through charging commission on sponsorship/visa/work permit, although the migrants were given the impression that these payment were being made to middle men/agents/ employers etc. and not to him. Thus the prospective migrant remains under the impression that his contact is facilitating his migration in Lebanon on friendly/family basis without any charge.” (Gaur and Saxena) ${ }^{117}$
\end{abstract}

As far as migrant workers in the field of construction are concerned, a migrant construction worker ${ }^{118}$ in a leading company in Lebanon informed us that he and his fellows on the construction sites work seven days a week from 6:00 AM till 8:00 PM and earn a monthly wage of 200 USD. They work under no contract and only benefit from insurance covering accidents during work time. According to him, construction workers are either illegal or are working with the consent of another employer. The Syndicate of Engineers has not so far integrated provisions pertaining to the right of foreign workers, disregarding the general international provisions of international labour organizations calling for the regulation of the terms of employment of migrant workers in all sectors.

On the other hand, Lina Hawi from "Le Marin" domestic worker recruitment agency in Hadath provided input on the terms applied in the agency. "Le Marin" offers two kind of services: full time worker and part time worker whereby in the former case, the employer is the housewife and in the latter it is the agency. For the first category, the workers are selected by the housewife based on a catalogue providing a photo and personal information on the migrant worker's religion, age and nationality. Once recruited, the worker lives in the employer house, and their their contract is signed in Arabic. Representatives from the agency explain to the migrant workers their rights including their wages, nationality and inform them that their employer will take possession of their passport. They however do not educate them on their right to work for only 8hours a day and to have a 24hour weekly rest as the signed contract between parties requires. Thus, it is an intentional withhold of information because it increases the obligations of both the agency and the employer, and both are not willing to be bound to it. In the second category, the workers lives in an underground warehouse and work from 6:00AM until 9:00PM. They might be deployed in houses, companies, hospitals etc. also for 7 days per week, under a work contract with the agency. Official inspection is often conducted by the Lebanese authorities in hospitals and companies where migrant workers work in order to check if the employers are implementing the terms of the contracts and respecting their rights ${ }^{119}$. Such inspections are not conducted however in the cases of in-house domestic workers, because the Lebanese law generally has a primacy for the privacy of the household, granting the family the right to refuse to allow an inspector to enter the house in order to see if the worker is well treated. Subsequently, even if recruitment agencies are willing to start implementing or enforcing the implementation of the new law, they cannot do much because the Ministry of Labour remains very discrete regarding this issue ${ }^{120}$.

\footnotetext{
117 Gaur, Seema, and Prem, Saxena (undated) Networks Perpetuating Labor Migration from India to Lebanon: A Comparative Study from the States of Punjab and Tamil Nadu. http://iussp2005.princeton.edu/download.aspx?submissionId=52510

118 The worker requested confidentiality.

${ }^{119}$ Interview with Maitre Hasna Reda, 17 January 2011.

${ }^{120}$ Phone interview with Lina Hawi, undated.
} 


\section{II.B.2. Labour organizations}

The General Confederation of Lebanese Workers (CGTL for the Confédération Générale des Travailleurs du Liban) was founded in 1958 and is defined as a "loosely organized national trade union center in Lebanon”. Presided by Ghassan Ghosn, it currently accounts for 200,000 members ${ }^{121}$. CGTL is a member of the International Trade Union Confederation and restricts membership to those with Lebanese citizenship. In fact, CGTL defends the rights of Lebanese workers and advocates for these rights before the government in order to regulate the flow of migrant workers into the country because migrant labour competes with the local one. Indeed the general policy of this confederation is to preserve the rights of the Lebanese workers from the migrant labour competition (namely illegal migrant workers) and this translates in the fact that migrant labourers are denied membership in CGTL. Nonetheless, representatives from the CGTL do not consider this practice as discrimination; they just do not prefer to encourage their increasing flow.

\section{II.C. Faith-based Organizations}

As it is the case in other areas of the Lebanese society, faith-based organizations play an important role in regulating migrant labour issues and problems namely with respect to protection of their rights.

\section{II.C.1. Caritas}

Caritas Lebanon was founded in 1972 as a member of Caritas Internationalis, a worldwide confederation among the largest humanitarian networks, including 162 Catholic organizations operating in 200 different countries. The core values of this faith-based organization are human dignity, special concern for the poor, fostering self-reliance, solidarity, transparency and cooperation. Among its various charitable activities, Caritas pays close attention to the rights of migrants, namely migrant workers in Lebanon, whose dignity is widely abused, who are generally poor and highly dependent on their employers, and who suffer from the lack of solidarity from the Lebanese social and legislative system. Caritas has been known to help migrants return home whenever it is possible, or mediate their settlements in a third country when official arrangements are made. It also offers a prison aid program to assist the detained migrants who have been caught with no or invalid working documents. The center also provides free medication to poor migrant workers, insurance services to migrant workers under its care, as well as advice and training in the setting up of small businesses or in handicrafts.

Caritas has a Memorandum of Understanding (MoU) with some countries of origin of migrant workers in Lebanon and is currently working on establishing further MoUs with additional countries. Caritas also signed bilateral agreements with the Syndicate of agencies, and is currently preparing for and MoU with the Ministry of Labour. Caritas has been involved in the reforms that have been slightly introduced to the migrant workers issues in Lebanon. Of the reforms are the release of the migrant worker from one employer to another upon consent of both parties; the reform with the National Steering Committee officially established in 2007 and currently focusing on anti-trafficking legislation as well as on a unified contract providing for the rights and obligations looking at the existing legal provisions. The Committee was established under the auspices of the Ministry of Labour to follow up on the recommendations from a workshop conducted by the ILO, OHCHR, UNIFEM and Caritas in 2005. The ILO provided technical support and resource mobilization (presenters, trainings...) "to build capacities of the National Steering Committee members." 122 The National Steering Committee is made up of the General Director of the Ministry of Labour, legal, educational, and social representatives from the Ministry, as well as representatives of the ILO, the UNHCR, General

\footnotetext{
${ }^{121}$ Retrieved online at http://en.wikipedia.org/wiki/General_Confederation_of_Lebanese_Workers on 28 February 2010

${ }^{122}$ Action Brief on Migrant Domestic Workers in Lebanon, Draft, ILO Regional Office for arab States, September 2010.
} 
Security, the Syndicate of Lawyers, the Syndicate of recruitment agencies of Migrant Domestic Workers, Caritas, the Ministry of Foreign Affairs and the Ministry of Social Affairs. The main aim of this Committee is to establish programs to improve the situation of MDWs and ensure their protection, to optimize the coordination between official agencies and special committees, ILO and various national, regional and international institutions concerned with the MDWs' rights, increase awareness and draft national policies ${ }^{123}$.

Caritas acknowledges ${ }^{124}$ a series of problems in the migrant labour realities in Lebanon: their exclusion from the domestic labour law, the Kafeel or sponsorship system, and the ambiguities within the newly established unified contract. Ongoing efforts of Caritas include discussions on policies towards reforming temporary migration schemes in the country, namely within the activities of the national steering committee towards introducing legislation on trafficking, sexual abuse and irregular pay of migrant workers. Moreover on the advocacy front, Caritas suggests some steps contributing to the reform of migrant labour management in Lebanon. These steps include: setting a code of conduct based of international conventions that would bind embassies and relevant institutions; advocating for the ratification of the relevant international conventions for the protection of migrant workers; and considering the possibility of allowing dependants of migrant workers to reside in Lebanon during the temporary duration of employment.

Furthermore, as part of raising awareness of the migrant workers towards their rights within their hosting country, Caritas suggested to set up a welcome desk in the airport to provide incoming migrant workers with information necessary for their stay. Pressure from other parties hindered this initiative. Caritas continues to pursue its efforts at present times by preparing a project to establish a "real" health coverage for migrant workers, as well as a project to found a cultural center for migrant workers where they can spend their days off and where they can enroll in multiple vocational trainings. The plan to establish a welcome desk at the airport as well as on the creation of a handbook ${ }^{125}$ to be distributed in sending countries and in Lebanon (in different languages) is also a part of the ILO's strategy for 2011-2012. This highlights the agreement of multiple players on the need to education migrant workers on their rights and obligations prior to their placement in Lebanon ${ }^{126}$. In addition, Caritas has launched a pre-training program for migrant workers prior to their departure from their home country. The program aims to train them on their basic rights and responsibilities, as well as to provide them with a language guide. The program has completed so far the training of trainer phase.

Faith-based institutions can provide an important link to migrant communities and constitute major partners to other non-governmental and civil society movement for the protection of migrant workers' rights. According to Kafa representative:

"Sunday services may be the only opportunity for migrant domestic workers to leave the house of their employers and to meet others from their communities. It was important for KAFA to meet with church leaders to inform them of KAFA's project for Migrant Domestic Workers (MDWs) and to understand how religious communities support their members. Sunday services provided KAFA a unique opportunity to meet and speak with many migrant domestic workers. Additionally, a number of migrant community leaders are also active members of their religious communities, indicating that faith-based institutions are important institutions for migrant workers”.

\footnotetext{
${ }^{123}$ Rules of procedure of the National Steering Committee, 2007

${ }^{124}$ Interview with Ms. Najla Chahda, Director at Caritas Migrant Center, Lebanon, 20 January 2011

${ }^{125}$ In this perspective, the Institute for Women's Studies in the Arab World (IWSAW) provided a brochure of relevance in 5 different languages.

${ }^{126}$ Interview with Simel Esim \& Gudrun Jevne - Gender and Women workers' specialist / ILO Regional Office For Arab States, January 18, 2011
} 


\section{II.C.2. The Pastoral Care of Afro-Asian Migrant Workers (PCAAM)}

The Pastoral Care of Afro-Asian Migrant Workers (PCAAM) "probably [provides] the most active

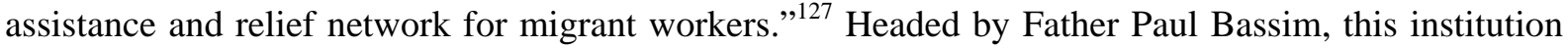
of the Catholic Church conducts various activities aiming to enhance the status of migrant workers in Lebanon, coordinated by Father Martin McDermott, a Jesuit priest at Saint Joseph University of Beirut. Although the PCAAM is specifically concerned with issues faced by non-Arab African and Asian migrants from countries with Christian communities, it also deals with "hundreds of thousands of mostly Muslim migrant workers from Arab countries". According to Father Mc Dermott, the PCAAM provides "pastoral care, [that is] not only religious assistance, but also a social and juridical assistance" (Ibid). On the one hand, the organization works to maintain a link between migrant workers in Lebanon and their relatives and family members in their home countries. On the other hand, the PCAAM also works to strengthen the bond between migrant workers and the Church as to ensure that the time of their stay in Lebanon is considered a "period of spiritual contentment and instruction" through religious orientation and catechism (Ibid). Nonetheless, the PCAAM realizes the need to provide further practical assistance in relation to generally pro-bono juridical assistance in cases of abused migrants or other problems they face ${ }^{128}$.

\section{II.D. Actual Implementation of all the above mentioned rules and regulations based primarily on NGO reports, interviews, media reports}

The categories of foreign labour in Lebanon in 2010 are presented as per country of origin in the table below ${ }^{129}$. The total accounts for around 146,000 migrant workers in Lebanon while various labour and migration institutions inform of a higher number that reaches 200,000 migrant workers in the country.

\footnotetext{
127 http://www.lnf.org.lb/migrationnetwork/ngo.html\#1

128 Interview with Father Martin Mc Dermott, 18 January 2011

${ }^{129}$ Martin J. Mc Dermott, Report of the Committee on Pastoral Care of Afro-Asian Migrant (PCAAM) workers in Lebanon to its president Bishop Elias Nassar, Beirut, July 13, 2010, pp. 3
} 
Table 1. Breakdown of foreign labour in Lebanon as per nationality

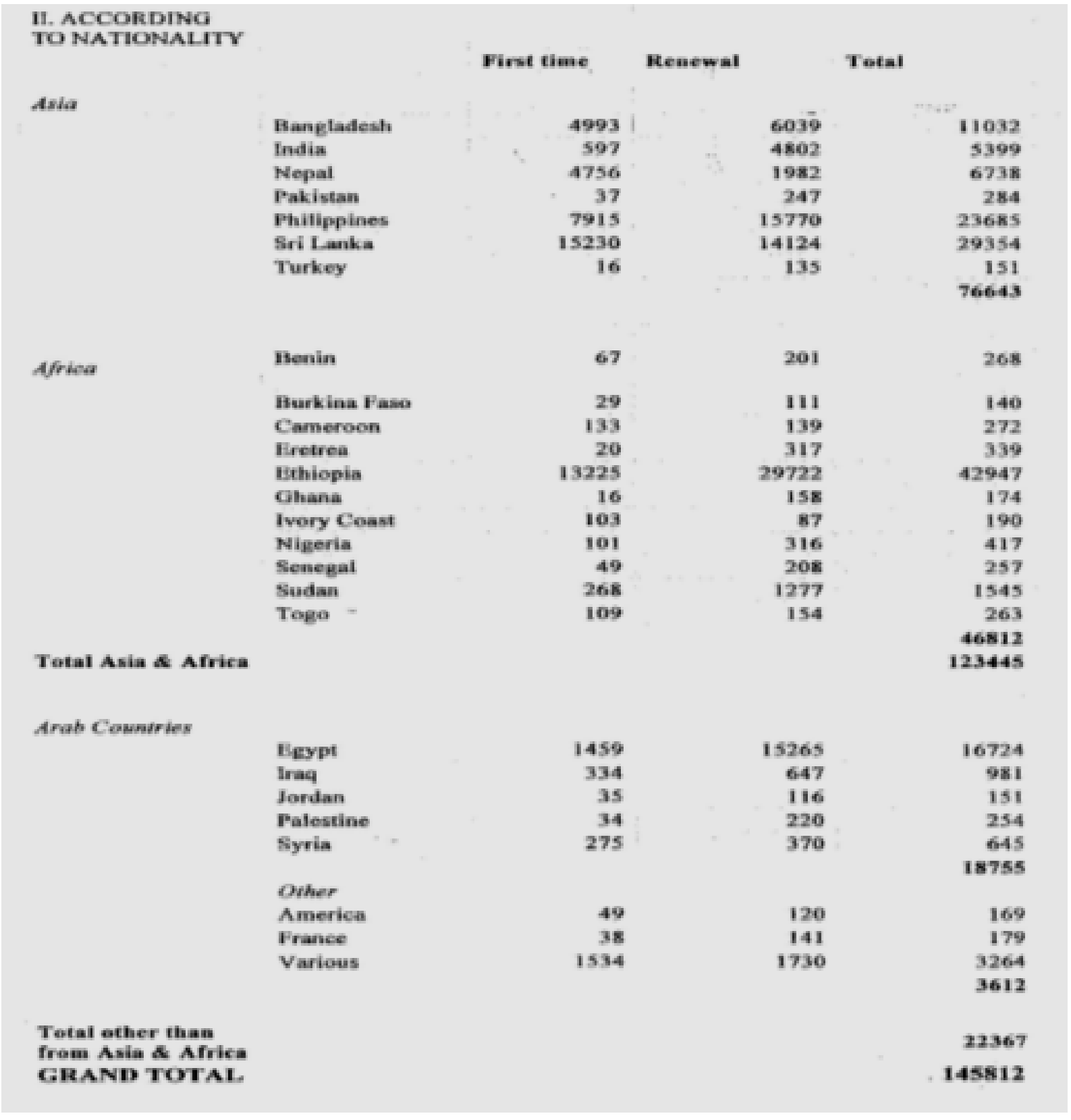

Although accounting to the Arab migration schemes into Lebanon, this report does not focus elaborately on this category of migrant workers; rather, it focuses on non-Arab namely Afro-Asian migrant workers. Regardless of their nationality distribution, temporary migrant workers fill in various labour categories in Lebanon varying in their skill requirements. Categories of temporary migrant labour include the following: cleaning workers (in-house or domestic workers (MDW), hotel cleaners, or hospital cleaners), nurses, construction sites workers, and workers on gas stations and other private institutions. Research on the various functions assumed by migrant workers in Lebanon has generally revolved around MDWs, thus most of the evidence provided in this report also reflect this reality. This category of labour was assumed by young Lebanese women low economic status families or women from neighboring Arab countries such as Palestinians, Kurdish, Egyptians and Syrians. According to 
Nayla Moukarbel (as cited in the Human Rights Watch Report of September $2010^{130}$ ), nationalities of MDWs shifted to Afro-Asians in the aftermath of the Lebanese Civil war due to various determinants: the cheaper cost of their labour, their submissive reputation, as well as the emerging inter-Lebanese conflicts and rising tensions against Syrians and Palestinians. Unfortunately, the trend changes resulted in a lower esteem vis-à-vis Afro-Asian migrant workers and thus devalued the categories of labour which they assumed. While the majority of MDWs are females, Indian males constitute a significant portion of migrant workers in the country. They work in different sectors namely "factories manufacturing various goods, construction workers, in service sector such as driver, cook, etc. [...] working in clubs, petrol pumps, hotels etc" (Gaur and Saxena ${ }^{131}$ ).

Most migrant workers in these categories of labour are illiterate or have withdrawn from school mainly due to poverty in their home countries, and generally relied on mobilizing resources from their family members and relatives, selling property (land, house etc.) to be able to afford their ticket. Regardless of their educational background, they end up engaging in unskilled and basic jobs ${ }^{132}$.

At this stage, it is worth stopping to comment on the numerical data accounting for migrant workers in Lebanon: governmental and non-governmental institutions (i.e. NGOs and the Ministry of Labour) each have their own way to calculate numbers and initiate statistics. In fact, the number provided by national authorities does not reflect exact numbers as they only account for migrant workers registered at the ministry. However, 50 to $70 \%$ of migrants leave their jobs, run away from their employers for different reasons, and end up working as freelancers and do not take part in the total official count. Even embassies of countries importing migrant workers to Lebanon fail to provide an exact number of their constituency in the country, and generally end up giving exaggerated estimations. Moreover, Human Rights Watch reports base their statistics mainly on target groups in Beirut thus disregarding significant numbers of migrants in the Bekaa, Tripoli, Saida and the rest of Southern Lebanon. These numbers also serve the Indyact movement when they report deaths of migrant workers at the rate of one per day since 2007. In sum, statistical data on the number of temporary migrant workers in Lebanon at any given time presents a range of inconsistencies due to a considerable percentage of those migrants not officially registered with the Lebanese authorities (having left their old job and working as freelance now). It is also due to the inflated estimations provided by embassies of the migrant workers, as well as to the restrictive data to the capital rather than a comprehensive screening of the distribution of migrant workers across the entire Lebanese territory.

Remittances: Migrant workers not only contribute to the economy of their hosting countries, but also to their countries of origin whereby they send significant remittance on a monthly basis to their dependants at home. The Central Bank of Lebanon provides statistics on the remittances that migrant domestic workers transfer electronically to their home countries. The figures in the first half of 2009 show 37,5 million USD to the Philippines, 27 million to Ethiopia, 17,8 million to Sri Lanka and 9,2 million to Bangladesh (Central Bank reported in Le Commerce du Levant, No.5603, April 2010, p. $26^{133}$ ). During the interviews held with the Ambassadors of Sri Lanka and the Philippines, they informed us that their migrant worker constituencies in Lebanon send respectively around 18 million USD and 108 million USD in remittances per year. The size of remittance highly depends on the monthly salary that may vary as well as on the overall number of the migrant worker communities.

Remittances do not solely benefit the migrant workers' family members back in their home countries but also play a role in clearing the debts that some of them resort to in order to finance their

\footnotetext{
130 http://www.hrw.org/en/reports/2010/09/16/without-protection?print

131 Gaur, Seema, and Prem, Saxena (undated) Networks Perpetuating Labor Migration from India to Lebanon: A Comparative Study from the States of Punjab and Tamil Nadu. 
migration: "Such migrants who came to Lebanon like this spent couple of years just paying back the loan” (Seema and Saxena ${ }^{134}$ ).

Contractual provisions and terms of employment: With respect to the contractual provisions of migrant employment, the Lebanese Ministry of Labour introduced a unified contract for all incoming domestic workers to Lebanon from all nationalities on January 31, 2009. Various stakeholders found ambiguities in the contract and lost hope of its actual effect due to its availability in one language, Arabic $^{135}$, and issued by notaries. In all cases, "few employees concern themselves with the details of the contracts in terms of requesting or insisting that the terms and conditions be complied with" (Jureidini, 7). Jureidini also notes that the duration for the employment contract varies between a minimum of one year to a maximum of three. According to legal provisions, the employer is obliged to provide the employee with a plane ticket at the end of his or her employment contract, in case of non-renewal. There are uncounted cases where the contract is not renewed and the worker resides in Lebanon illegally.

Working Conditions and abuses: The Human Rights Watch 2010 report "Without Protection ${ }^{136,}$ outlines further problems pertaining to the labour migrant workers falling in the category of domestic workers. Such problems and abuses include: unpaid and/or underpaid wages; confiscation of the passports; compulsory confinement and restricted communication with fellow workers or family in their home countries; heavy workload (working hours can reach beyond 60 hours per week); food deprivation and inadequate living and working conditions; psychological, physical, and sexual abuse; as well as the abuse by the recruitment agency mainly through monopoly of salaries at least for the first couple of months ${ }^{137}$. These problems were also highlighted by the representatives of the migrant workers' embassies during interviews and constitute the main reasons behind numerous attempts of Migrant Domestic Workers to "run away" and end up either convicted of theft and illegal breach of employment contract, deportation, or even death. In fact, between January 2007 and August 2008, "at least 95 migrant domestic workers have died in Lebanon [...]: 40 are classified by the embassies of the migrants as suicide, while 24 others were caused by workers falling from high buildings" [in an attempt to flee their employers, only 14 domestic workers died because of diseases or health issues" (Human Rights Watch ${ }^{138}$ ). In parallel, the perceptions that employers have vis-à-vis their Migrant Domestic Workers' rights play a significant role in determining the work conditions that they provide to their MDWs. The 2008 study prepared by IPSOS for Caritas Migrant Center describes an improvement in these existing perceptions as well as a comparison with the practiced behaviors of employers towards their domestic workers (Table 2 and 3 below).

\footnotetext{
134 Gaur, Seema, and Prem, Saxena (undated) Networks Perpetuating Labor Migration from India to Lebanon: A Comparative Study from the States of Punjab and Tamil Nadu. http://iussp2005.princeton.edu/download.aspx?submissionId=52510

135 Martin J. Mc Dermott, Report of the Committee on Pastoral Care of Afro-Asian Migrant (PCAAM) workers in Lebanon to its president Bishop Elias Nassar, Beirut, July 13, 2010, pp. 6

${ }^{136}$ Retrieved online at <http://www.hrw.org/en/reports/2010/09/16/without-protection?print>

${ }^{137} \mathrm{http}: / /$ www.hrw.org/en/node/93004/section/6

1382008 Lebanon: Migrant Domestic Workers Dying Every Week. August 24, 2008. http://www.hrw.org/en/news/2008/08/24/lebanon-migrant-domestic-workers-dying-every-week
} 
Table 2. Perceived Rights of Housewives over their Maids vs. Housewives Rights in Actual Practice

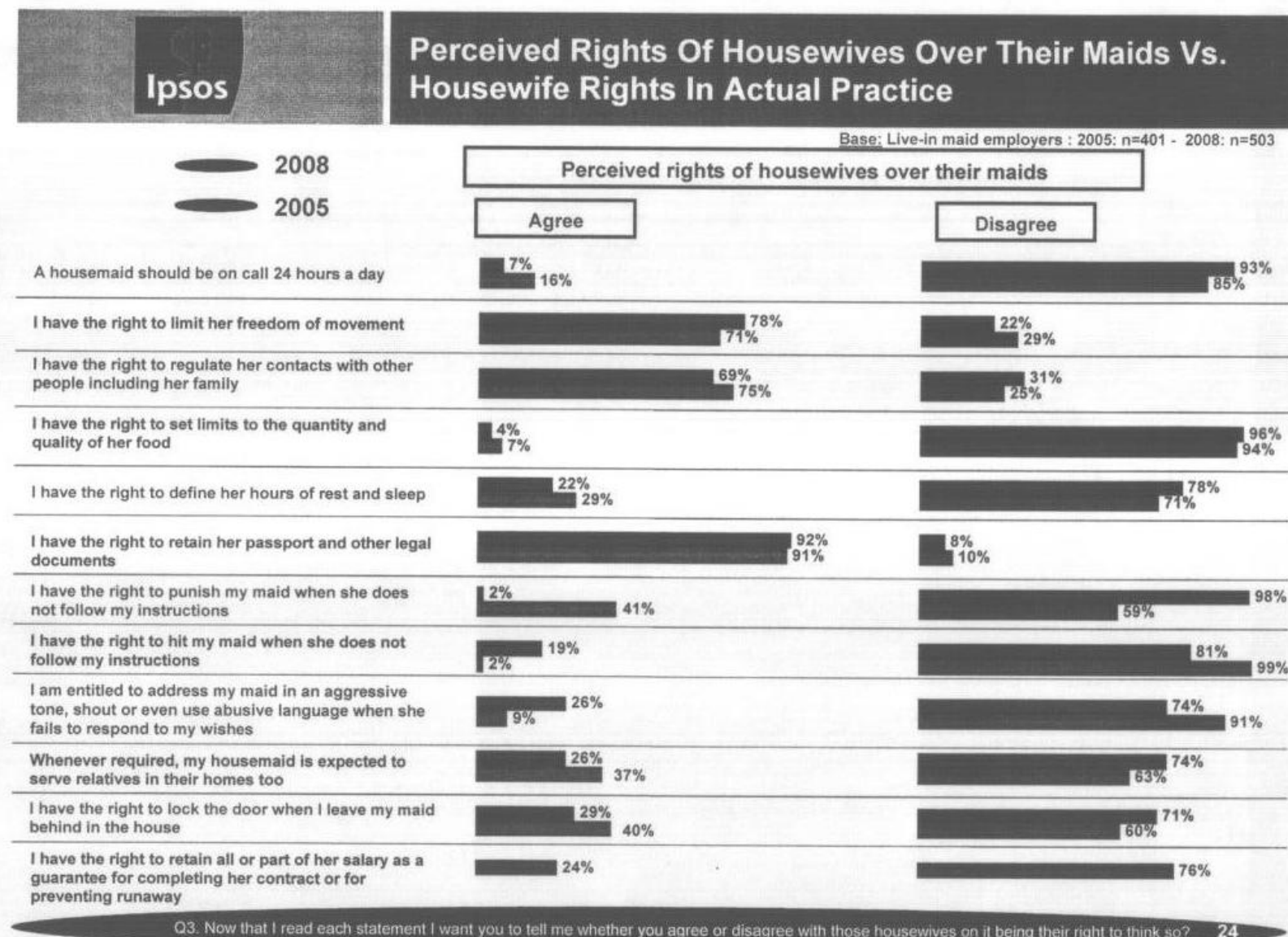


Table 3. Perceived Rights of Housewives over their maids vs. Housewife Rights in Actual Practice

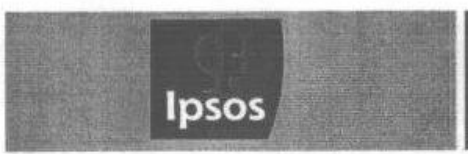

\section{Perceived Rights Of Housewives Over Their Maids Vs. Housewife Rights In Actual Practice}

\begin{tabular}{|c|c|c|c|c|c|c|c|c|}
\hline & \multicolumn{8}{|c|}{ Base: Live-in maid employers : $2005: n=401-2008: n=503$} \\
\hline & Agree & $\begin{array}{l}\text { Yes, } \\
\text { regulariy }\end{array}$ & $\begin{array}{l}\text { Sometím } \\
\text { es: }\end{array}$ & $\begin{array}{l}\text { No } 7 \\
\text { Never: }\end{array}$ & Agree & $\begin{array}{l}\text { Yes, } \\
\text { regulariy }\end{array}$ & $\begin{array}{c}\text { Sometim } \\
\text { es }\end{array}$ & $\begin{array}{l}\text { No } / \\
\text { Never }\end{array}$ \\
\hline $\begin{array}{l}\text { A-A housemaid should be on call } 24 \text { hours a } \\
\text { day }\end{array}$ & $7 \%$ & $5 \%$ & $7 \%$ & $89 \%$ & $16 \%$ & $36 \%$ & $11 \%$ & $54 \%$ \\
\hline $\begin{array}{l}\text { B-I have the right to limit her freedom of } \\
\text { movement }\end{array}$ & $78 \%$ & $65 \%$ & $18 \%$ & $17 \%$ & $71 \%$ & $64 \%$ & $17 \%$ & $19 \%$ \\
\hline $\begin{array}{l}\text { C-I have the right to regulate her contacts } \\
\text { with other people including her family }\end{array}$ & $69 \%$ & $57 \%$ & $16 \%$ & $27 \%$ & $75 \%$ & $73 \%$ & $14 \%$ & $13 \%$ \\
\hline $\begin{array}{l}\text { D-I have the right to set limits to the } \\
\text { quantity and quality of her food }\end{array}$ & $4 \%$ & $4 \%$ & $3 \%$ & $93 \%$ & $7 \%$ & $33 \%$ & $2 \%$ & $65 \%$ \\
\hline $\begin{array}{l}\text { E-I have the right to define her hours of rest } \\
\text { and sleep }\end{array}$ & $22 \%$ & $15 \%$ & $15 \%$ & $71 \%$ & $29 \%$ & $40 \%$ & $17 \%$ & $44 \%$ \\
\hline $\begin{array}{l}\text { F-I have the right to retain her passport and } \\
\text { other legal documents }\end{array}$ & $92 \%$ & $91 \%$ & $2 \%$ & $7 \%$ & $91 \%$ & $90 \%$ & $2 \%$ & $8 \%$ \\
\hline $\begin{array}{l}\text { G-I have the right to punish my maid when } \\
\text { she does not follow my instructions }\end{array}$ & $2 \%$ & $2 \%$ & $1 \%$ & $97 \%$ & $41 \%$ & $34 \%$ & $26 \%$ & $39 \%$ \\
\hline $\begin{array}{l}\text { H-I have the right to hit my maid when she } \\
\text { does not follow my instructions }\end{array}$ & $19 \%$ & $6 \%$ & $16 \%$ & $79 \%$ & $2 \%$ & $31 \%$ & $1 \%$ & $68 \%$ \\
\hline $\begin{array}{l}\text { I-I am entitled to address my maid in an } \\
\text { aggressive tone, shout or even use abusive } \\
\text { language when she fails to respond to my } \\
\text { wishes }\end{array}$ & $26 \%$ & $4 \%$ & $30 \%$ & $66 \%$ & $9 \%$ & $28 \%$ & $16 \%$ & $57 \%$ \\
\hline $\begin{array}{l}\text { J-Whenever required, my housemaid is } \\
\text { expected to serve relatives in their homes } \\
\text { too }\end{array}$ & $26 \%$ & $6 \%$ & $27 \%$ & $68 \%$ & $37 \%$ & $44 \%$ & $21 \%$ & $36 \%$ \\
\hline $\begin{array}{l}\text { K-I have the right to lock the door when I } \\
\text { leave my maid behind in the house }\end{array}$ & $29 \%$ & $18 \%$ & $8 \%$ & $74 \%$ & $40 \%$ & $54 \%$ & $8 \%$ & $38 \%$ \\
\hline $\begin{array}{l}\text { L- I have the right to retain all or part of her } \\
\text { salary as a guarantee for completing her } \\
\text { contract or for preventing runaway }\end{array}$ & $24 \%$ & $14 \%$ & $8 \%$ & $78 \%$ & - & - & - & - \\
\hline
\end{tabular}

Migrant workers generally find themselves very vulnerable to face their abuses within a justice system that does not play in favor of their rights. In fact, the quasi or sometimes total absence of access to communication facilities prohibits them from contacting relevant authorities to report violations held against them. Moreover, the limited employment periods of migrant workers compared to timely judicial processes, in addition to the sponsored or "kafeel" system in the case of MDWs, makes them reluctant to file a complaint against their employer and increases their fear of being expatriate. In this latter situation, MDWs are generally inflicted with the burden of paying their flight back home themselves, or being detained in General Security. If and when overcome, these obstacles are aggravated by many others such as absence of common language while filing a complaint, the frequent abusive practices during interrogation, as well as the lack of defensive lawyers and the cost of their services.

The role of the social partners in Lebanon concerning temporary migration issues mainly consists of attempting to improve the socio-economic status of migrant groups, namely illegal workers and domestic servants (CARIM, Lebanon Country Migration Report). The Pastoral Afro-Asian Migrant Center, Caritas Migrant Centre, the Council of Middle Eastern Churches and Najdeh are very active in this respect. Further efforts are conducted towards extending access to information pertaining to the rights of migrant workers and domestic workers, as well as to raising awareness as the human rights of refugee communities, which is not the focus of our discussion. 


\section{Discrepancies between Sections I. and II.}

The overview presented on international and regional guidelines established to provide a framework for the management of migrant labour issues and the evidence provided on the existing realities in Lebanon match both match and mismatch at different instances. The following section provides a comparison between these two areas.

\section{III.A. Comparison of International Norms and Formal Reality in Lebanon}

There is a clear gap between the international guidelines provided for in international conventions and multilateral frameworks for the regulation of labour migration schemes and the formal reality in Lebanon, mainly in the area of national policy. In their majority, international conventions and legally binding instruments call for the formulation of adequate domestic rules and regulations, which aim to regulate labour migration schemes and monitor violations against migrant workers. The marginalization of migrant workers from the Labour Law is in direct violation of the right to fair and equal treatment of migrants compared to Nationals before the law. Further, the absence of a national strategy that offers a comprehensive plan to manage labour migration in the country minimizes the impact of solo attempts that various players make to improve the status of this vulnerable group.

Lebanon is still behind in terms of codifying key legal instruments such as the United Nations International Convention on the Protection of the Rights of all Migrant Workers and Members of their Families. Consequently, Lebanon still falls outside the realm of international responsibility towards the protection of migrants' rights, and fails to direct its social and economic policies in to address this issue more adequately. Furthermore, the country's bouncing political priorities and the tight association of the issue of migrants with sensitive matters such as that of the Palestinian refugees for instance, delay legislative reforms from taking place.

\section{III.B. Comparison of Formal Level (International and National Norms) to Actual Implementation}

Despite its minute reforms, Lebanon remains a major violator of the rights of migrant workers in various respects. Various incidents of deaths reported by Human Rights Watch and the Migrant Rights Organization ${ }^{139}$ either result from violence of from attempts that MDWs make to run away from their abusive employers. Both cases are a clear violation of the international guidelines of the UN Declaration of Human Rights, the International Covenant on Civil and Political Rights, and the International Convention on the Rights of all Migrant Workers and Members of their families, providing for the ban of torture, physical abuse and the right to humane treatment and decent work and living conditions. Further, the common trend of confiscating passports of in-house migrant domestic workers by the employer challenges the right of the migrant workers' to move freely, and to make choices pertaining to their employment, called upon by the above-mentioned conventions. The overwhelming working hours and additional workload, which are not fairly compensated financially in both areas of MDWs and construction workers accounted for earlier in this report, are also in contradiction with the terms and obligations also set by these conventions and by the International Covenant on Economic, Social and Cultural Rights. Moreover, evidence on the violations of the rights of migrant workers to rest and recuperate by recruitment agencies, namely in the field of construction and domestic work proves the non-compliance of employers organizations to international norms of foreign labour.

On another front, the challenges we faced in accessing accurate information addressing temporary foreign workers in Lebanon presents the extent to which the country fails to collect, integrate, and disseminate such information. The ILO conventions call upon an increased coordination among the different stakeholders in order to exchange information and accordingly formulate adequate

\footnotetext{
139 http://www.migrant-rights.org/2010/08/25/lebanon-increase-in-death-of-migrant-domestic-workers/
} 
educational programs increasing the knowledge of migrant workers, employers and other relevant players on their respective rights, obligations and tools to monitor them. In addition, the Multilateral Framework set by the ILO, although non-binding, constitutes a political and ethical obligation on governmental and non-governmental actors, and clearly undermined by the existing practices in Lebanon. In fact, evidence collected from the various interviews conducted for the purpose of this research proves the intentional withhold of valuable information by employers' organizations vis-à-vis their employees because of the legal obligations they entail. Recruitment agencies for instance prefer to omit the rights of the migrant workers they employ while they insist on their obligations and duties towards their employers.

In all, the perceptions (or better say the misperceptions) of the employers, the interests of the agents, the inertia of the government and the overall devalued status of migrant workers resulting from their assumed positions (mainly unskilled or under-skilled jobs) combine to shape the reality of these workers in Lebanon. It is also important to add another factor that is the restriction set on migrant workers from joining the CGTL and thus depriving them from their right to freedom of association. These factors, among others, have made these workers far from enjoying their basic rights as human beings and have not managed to prove their jobs as "real jobs". The inertia of the Lebanese state in introducing reforms is exacerbated by pressures from international players on the one hand and by the vivid civil society players.

\section{III.C. Recommendations for Elevation of Discrepancies}

Based on the slow reforms taken to improve the situation of migrant workers in Lebanon as well as on the complexity of the sectors involved in temporary labour migration schemes, one can propose the following recommendations. Although each of these opportunities constitutes a step forward, they should all be integrated in a comprehensive national strategy for the regulation and the management of Temporary Labour Migration. The strategy thus would include (yet does not consist only of):

International Legislation: Lebanon's Parliament shall ratify all International Conventions pertaining to the rights of migrant workers. The reluctance of the Lebanese authority to commit to further international obligations has reflected badly on its human rights records generally. Although the country has ratified some UN and ILO conventions relevant to this issue, it has failed however to properly implement the terms of these international instrument due to various factors, namely the poor interpretation and incorporation of these provisions within a comprehensive national policy. As it is the case in the interpretation and implementation of any international instrument, it is very critical however to apply "universal" norms in a manner that is "culturally fit".

National Legislation and Judiciary: it is not enough for Lebanon to adhere to international guidelines which the authorities do not embody in their practices. The role of the Lebanese government shall be enhanced to tackle a web of issues related to temporary migrant labour namely at the level of policy formulation, policy implementation, monitoring and regulation as well as penalization of non-compliance. Further, the judiciary shall enforce its authority in cases on conflicts and provide equal opportunities to both national workers and migrant workers. "Without Protection" of the Human Rights Watch ${ }^{140}$ touches upon the lack of judicial support to migrant domestic workers labour issues even when it relates to national labourers:

"Lebanon's judiciary has both the potential and obligation to play an important role in protecting the basic rights of MDWs. However, this potential has so far remained unfulfilled, and the judicial system remains, albeit with exceptions, largely inaccessible and unresponsive. Such problems are not limited to MDWs: many Lebanese also suffer from lengthy pre-trial detentions, extended trials, and overloaded courts. However, MDWs face particular obstacles in accessing the justice system.”

\footnotetext{
${ }^{140}$ http://www.hrw.org/en/reports/2010/09/16/without-protection?print
} 
Social Partners and Civil Society: the dearth of formalized information and data available on the Lebanese social partners contradicts with the wealth of the initiatives conducted by civil society movements to address problems of migrant workers and those most vulnerable of them. Further investigations shall be conducted mainly in the area of labour unions and employers organizations. "Research and science are necessary tools. They give further advantages to the trade union movement for it to address youth, women, intellectuals, economic immigrants whose entering trade unions will revive the labour movement. It is essential that new trade union members have a higher educational, cultural and intellectual level."

Developmental perspective: In her February 2007 article on "Linking Temporary worker Schemes with Development" Dovelyne Agunias from the Migration Policy Institute reflects the lack of consideration to the developmental approach to temporary migration schemes. It informs of a policy brief from the Organization for Economic Cooperation and Development (OECD) which proposes that "development-friendly temporary programs should be associated with more flexible and open working arrangements" because current trends characterized by "fixed duration of stay, uncertain prospects for return and tying of workers to specific employers" do not contribute to development. In this perspective, both countries exporting and importing migrant workers are concerned with attempting a different approach to this issue, mainly by considering this category of labourers as a substantial cornerstone of their economic development and prosperity.

\section{Conclusion}

It is worth mentioning at this stage that the implementation phase of this project started during the second week of January 2010, which was marked by the collapse of the coalition government on January 12, 2010. The event resulted in an atmosphere of insecurity across the country, namely within and around governmental agencies and official institutions, which made the interviewing process very challenging ${ }^{142}$. Field reports recorded, inter alia, a series of challenges in terms of this insecurity, a varied level of cooperation among the concerned parties (embassies, organizations etc...), as well as difficulties in accessing official statistical data.

However, it is clear by now that major gaps still exist between the ideal protective guidelines regulating migrant workers and the realities on the Lebanese ground. Reforms are necessary to ensure that the minimum human rights of these workers are obtained. First, migrant workers should be explicitly integrated as key targets of the Lebanese national labour policies as endorsed in the Labour Laws. It is a key step in acknowledging that migrant workers are treated equally as national workers with regards to their rights, obligations, and legal status. Legal reform has always been controversial in Lebanon as it does not ultimately lead to actual reform on the ground of reality because of the country's well instilled culture of impunity. A law without an enforcement mechanism is as good as no law; thus the establishment of a sound web for the implementation of international and national guidelines which involves national governmental authorities, international governmental and nongovernmental institutions, social partners and faith-based organizations active in the sector, and most importantly the migrant workers themselves, who - it is clear by now through this report - have very little if any voice in determining their status in their hosting country. For this purpose, the regulation and management of temporary labour migration issues shall no longer be restricted to the Ministry of Labour, Interior and Social Affairs alone, but also to the Lebanese Ministry of Justice and the Judiciary as well as the Lebanese Parliament and Cabinet as a whole. These latter do not currently play a substantial role in the protection of the rights of migrant workers, and should become more active in the formulation and implementation of laws pertaining to these rights, monitoring the enforcement of

\footnotetext{
${ }^{141}$ The International Labour and Trade Union Movement in the $21^{\text {st }}$ century, retrieved online on 28 February 2011 at http://www.wftucentral.org/?page_id=40\&language=en

142 One of our field researchers struggled to travel across Bechara El Khoury due to the mass gatherings of opposition constituencies in Beirut neighborhoods of Tayyouneh, Zaqaq al-Blat, Ras al-Nabeh and Bechara al-Khoury for instance.
} 
these laws and otherwise introducing penalties while providing for an equally fair justice system which resolves tripartite disputes between workers, employers and recruitment agencies. In addition, legislative efforts shall not be narrowed to national regulations but also to the ratification of key international obligations which guide migration schemes and provide for a wide forum of best practices and benchmarks.

This text was largely compiled by Pamela Chemali under the supervision of the project leaders.

\section{Concluding Remarks}

A comparison of the application of international labour migration norms in Jordan and Lebanon indicates that both countries have demonstrated a propensity to formally adopt and ratify general codes and specific guidelines in this policy area, but then drag their feet when it comes to their implementation. Lebanon, however, has also proven unwilling to even formally introduce many key social rights for migrant workers. In the key area of labour union representation for example, Jordanian labour unions have taken steps to organize immigrant workers, as described in the case of the foreign textile workers above. There were no documented cases found for this report of the Lebanese labour unions intervening in support of non-Lebanese nationals. Thus, labour migrants remain completely without formal representation.

Lebanon has also proven to be relatively independent, when compared to Jordan, when it comes to bowing to the pressures emanating from the international community. Jordan's dependence on US aid has made it more willing to respond to criticism in the field of migrant workers rights. The very nature of the stratified Lebanese political system and its dependence on the various confessionally allied power elites has prevented significant reforms in the social policy arena. The labour unions have been particularly susceptible to sectarian strife and meddling in their internal leadership structures. This is most likely one of the main reasons for their reluctance to champion the cause of migrant workers. With respect to the employers organization in Jordan and Lebanon, this survey has found no evidence that they have taken any steps whatsoever to fulfill their (albeit nonbinding) obligations within the context of the ILO Multilateral Framework on Labour Migration.

This policy vacuum, especially in the case of Lebanon, has been largely filled by international and domestic NGOs. In confessionally diverse Lebanon, the Christian faith-based organizations (or FBOs) has proven to particularly dynamic. Although their proactive role is laudable, their success may be considered counterproductive when it comes to dealing with tripartite policy reform. In many cases FBOs and secular NGOs have filled the gap left by inactive social partners when it comes to interacting with their respective governments. Increasingly, the civil society sector is also replacing the government itself. Because they lack formal legitimacy (NGOs are not elected by the client groups they serve), the growth of civil society is therefore in a way undermining the very nature of tripartite reform and social integration process.

The ultimate consequence of government intransigence and social partner inaction (or even outright opposition to reform) is an undermining of all attempts to empower the labour migrants themselves. Thus, it would seem that the most important reform proposal that this survey can offer is a call to reinvigorate the cooperative nature of labour policy development process on the international and regional level. Simultaneously they should encourage - or event pressure - the state and social partners on the national level to allow relevant government institutions, the employers associations, and most importantly the labour unions to integrate migrant workers in the policy reform process. 


\section{References}

Abi Samra, Marwan

2010 L'émigration Libanaise et son impact sur l'économie et le développement. Programme des Migrations Internationales, cahiers des Migrations Internationales, n ${ }^{\circ} 105$ BIT Genève, p8-10

Abella, M.

2006 Policies and best practices for management of temporary migration. International symposium on international migration and development. Turin: United Nations

Añonuevo, T.

2007 The Role of the Trade Union Movement in Migration and Development: A Contribution from the Building and Wood Workers International (BWI). International dialogue on migration intersessional workshop on making global labour mobility a catalyst for development. Geneva: IOM

Al Khouri, Riad

2007 "Aspects of Migration and Development in Jordan”, A paper prepared for the Migration and refugee Movements in the Middle East and North Africa, AUC, Cairo

Arouri ,A. Fathi,

"Non Jordanians Working in Jordan”, CARIM research report, 2007/5

“Circular Migration in Jordan 1995-2006”, CARIM research report, 2008/35

A.S.Zaghal and A.F. Dergarabedian

2004 "Migration- Related institutions and Policies in Jordan”, paper prepared on the social integration of immigrants, migration and the movement of persons, RSCAS

Chalcraft, John

2005 Of Specters and Disciplined Commodities: Syrian Migrant Workers in Lebanon. Middle East Report, No. 236 (Fall, 2005): 28-33.

Chammartin Moreno-Fontes, G.

2008 Migration, gender equality and development. International Conference on Gender, Migration and Development: Seizing Opportunities, Upholding Rights Manila: ILO IUF. 2008). Workers and unions on the move: Organising and defending migrant workers in agriculture and allied sectors. Retrieved from http://www.iufdocuments.org/www/documents/IUFmigrantworkersmanual-e.pdf

Collet, L.

(2008). The Civil Society Day of the Global Forum on Migration and Development. (Report No. D/2007/2893/52) Retrieved from

http://www.kbsfrb.be/uploadedFiles/KBSFRB/05)_Pictures,_documents_and_external_sites/09)_Publi cations/EndReportMigration\&Dev.pdf

De Bel Air, Francoise

2008 "Irregular Migration To Jordan: Socio-Political Stakes, CARIM research report, 2008/78

"Circular Migration To and From Jordan: An Issue of High Politics”, CARIM research paper, 2008/20

Di Bartolomeo, Anna, Fakhoury, Tamirace,\& Delphine, Perrin

2010 Liban le cadre démographique-économique de la migration, le cadre juridique de la migration, le cadre socio-politique de la migration. Euro-Mediterranean Consortium for Applied Research on International Migration (CARIM), European University Institute, Robert Schuman Centre for Advanced Studies, Florence, Italy. [French]

http://www.carim.org/public/migrationprofiles/MP_Lebanon_EN.pdf

2010“Migration Profile: Jordan”, CARIM research report, November 2010.

Dovelyn, Agunias

2007, Linking Temporary Worker Schemes with Development, Migration Policy Institute http://www.migrationinformation.org/Feature/display.cfm?ID=576 
European Commission (Economy)

2010 Labour Markets Performance and Migration Flows in Arab Mediterranean Countries Determinants and Effects, volume 1, European Economy Occasional papers n60 Avril 2010 Final report \& Thematic Background Paper

Gaur, Seema, and Prem, Saxena

(undated) Networks Perpetuating Labor Migration from India to Lebanon: A Comparative Study from the States of Punjab and Tamil Nadu

http://iussp2005.princeton.edu/download.aspx?submissionId=52510

Gloria Moreno- Fontes Chnnartin,

2005 Domestic Workers: Little Protection: for the Underpaid. International Labour Organizationn http://www.migrationinformation.org/Feature/display.cfm?id=300

Human Rights Watch

2008 Lebanon: Migrant Domestic Workers Dying Every Week. August 24, 2008.

http://www.hrw.org/en/news/2008/08/24/lebanon-migrant-domestic-workers-dying-every-week Arabic version - http://www.hrw.org/en/news/2008/08/24

Without Protection How The Lebanese system Fails Migrant Domestic Workers http://www.hrw.org/en/reports/2010/09/16/without-protection

International Labour Organization (ILO),

2008 Promoting the Rights of Women Migrant Domestic Workers in Arab States: The case of Lebanon. Issue Brief 1. Beirut: International Labour Organization, Regional Office for the Arab States

2004 "Gender and Migration in the Arab states: the case of domestic workers", edited by Simmel Esim and Monica Smith. ILO, Beirut Regional Office

IFBWW. (2004).

Exploitation of construction, forestry and wood workers in connection with migrant and cross border work. Retrieved from http://www.bwint.org/pdfs/migrantworkers.pdf

Ishikawa, J.

2003 Key features of national social dialogue: A social dialogue resource book. Retrieved from ILO, Dialogue Industrial and Employment Relations department website: http://www.ilo.int/public/english/dialogue/ifpdial/downloads/papers/key.pdf

ICFTU, WTL \& GUFs.

2006 Making the case for a rights-based approach to global migration policy, and for a transparent, inclusive consultative forum on international migration. The high level dialogue of the general assembly on the theme of international migration and development. New York: United Nations

ITCU,

2007 “Migrant workers in the Middle East”, CSI (Confederacion Sindical Internacional), Union view, December 2007

Jouni, Hassan

2008 Les immigrés illégaux au Liban. Approche juridique. Euro-Mediterranean Consortium for Applied Research on International Migration (CARIM), European University Institute, Robert Schuman Centre for Advanced Studies, Florence, Italy. [French] http://cadmus.eui.eu/dspace/bitstream/1814/10100/1/CARIM_AS\%26N_2008_55.pdf

Jureidini, Ray

2002 Women Migrant Domestic Workers in Lebanon. International Migration Papers 48. International Migration Programme. Geneva: International Labor Office

2009 In the Shadows of Family life: Toward a History For Domestic Service in Lebanon, Journal of Middle East Women’s Studies, 5 (3) (Fall 2009): 74-101 
Jureidini, Ray, and Nayla, Moukarbel

2004 Female Sri Lankan domestic workers in Lebanon: a case of 'contract slavery’? Journal of Ethnic and Migration Studies, 30(4) (July): 581-607

Mahdawi, Dalila

2009 Official to travel to the Philippines to discuss ending work ban, The Daily Star- Lebanon News

Mc Dermott, Martin.J

2010 Afro-Asian Migrants in Lebanon: Report of the Committee on Pastoral Care of Afro-Asian Migrant Workers (PCAAM), 13 July 2010, Beirut-Lebanon.

Meetings Coverage and Press Releases, United Nations. (2003, March 19). Convention on protection of rights of migrant workers to enter into force next July [Press Release]. Retrieved from http://www.un.org/News/Press/docs/2003/LT4371.doc.htm

Olwan, Mohamed Y. Olwan,

2008 "Circular and Permanent Migration: A Jordanian Perspective”, CARIM research paper, 2008/34.

"Gender and Migration in Jordan", CARIM research paper, 2010/66.

"High -Skilled Migration to and from Jordan”, CARIM research report, 2010/5.

OSCE, IOM, ILO

2006 Handbook on Establishing Effective Labour Migration Policies in Countries of Origin and Destination, Vienna

Peñalosa, A.

(2006). Remarks of the IOE. High-level inter-country consultation on the WHO global plan of action on workers health. Geneva: WHO

Progress report on Jordan, EU, Brussels, May 2010.

Thouez, C.

2003. The role of civil society in shaping international migration policy. Retrieved from http://sanford.duke.edu/centers/civil/papers/thouez.pdf

Young, Michael

2000 Migrant workers in Lebanon, Lebanese NGO Forum, September 2000. http://www.lnf.org.lb/migrationnetwork/mig1.html 


\section{Webography}

http://www.amnesty.org/en/news-and-updates/report/isolated-and-abused-women-migrant-domesticworkers-jordan-20081030

http://www.almanar.jo/AlManarWeb/Default.aspx?PageContentID=298\&tabid=113\#5

http://www.arabcci.org/IMAC_aboutus.htm

http://www.arabcci.org/membership.htm

http://www.arabhumanrights.org/en/countries/country.aspx?cid=7

http://www.lnf.org.lb/migrationnetwork/ngo.html\#

http://www.hrw.org/en/reports/2010/09/16/without-protection?print

http://www.hrweb.org/legal/cpr.html

http://www.migrant-rights.org/2010/08/25/lebanon-increase-in-death-of-migrant-domestic-workers/

http: //esa.un.org/undp/wpp2008/pdf/WPP2008_Hoghlights.pdf

http://www.executive-magazine.com/getarticle.php?article=11835

http://europenews.dk/en/node/3847

http://www.ituc-csi.org/migrants-in-jordan-how-the-unions.html?lang=en

http://www.iom.int/jahia/webdav/site/myjahiasite/shared/shared/mainsite/published_docs/serial_public ations/Glossary_eng.pdf

http://www.iom.int/jahia/jahia/about-migration/developping-migration-policy/migrationlabour/cache/offonce/

http://www.iom.int/jahia/jahia/activites/africa-and-middle-east/middle-east/jordan

http://www.jordantimes.com/index.php?news=30060

http://www.un.org/esa/polulation/migration/Turin/symposium-turin-files/P03-SYMP-Abela.pdf.

www.radio1812.net/circular-migration-\%E2\%80\%93-newform-temperory-labour-migration

http://unesdoc.unesco.org/images/0014/001435/143557e.pdf

http://www.unesco.org/most/migration/glossary_migrants.htm

http://www.unesco.org/new/en/social-and-human-sciences/themes/socialtransformations/international-migration/glossary/migrant/

http://www.unesco.org/education/information/nfsunesco/pdf/SOCIAL_E.PDF

http://www.hrweb.org/legal/cpr.html

http://www.un.org/womenwatch/daw/cedaw/text/econvention.htm

http://www.un.org/News/Press/docs/2003/LT4371.doc.htm

http://www.ilo.org/ilolex/cgi-lex/convde.pl?C097

http://www.ilo.org/ilolex/cgi-lex/convde.pl?C143

http://www.ilo.org/public/english/protection/migrant/download/multilat_fwk_en.pdf

http://www.ilo.org/sapfl/News/lang--en/WCMS_146786/index.htm 
http://www.ilo.org/global/topics/labour-migration/lang--en/index.htm

http://www.ilo.org/global/about-the-ilo/press-and-media-centre/insight/WCMS_075619/lang-en/index.htm

http://www.papalencyclicals.net/Pius12/p12exsul.htm

http://www.vatican.va/holy_father/benedict_xvi/encyclicals/documents/hf_benxvi_enc_20090629_caritas-in-veritate_en.html

http://www.carim.org/public/migrationprofiles/MP_Lebanon_EN.pdf

http://www.carim.org/public/legaltexts/LEB00241.pdf

http://www.carim.org/public/legaltexts/LEB00242.pdf

http://www.carim.org/public/legaltexts/LEB00243.pdf

http://www.osce.org/eea/19246

http://www.december18.net/international-ngo-platform-migrant-workers-convention-ipmwc

http://www.icatu56.org

http://www.ioe-emp.org/

http://www.ioe-emp.org/en/policy-areas/migration/index.html

http://www.iom.int/jahia/webdav/site/myjahiasite/shared/shared/mainsite/published_docs/serial_public ations/Glossary_eng.pdf

http://www.ituc-csi.org/

http://www.icftu.org/

http://www.poplas.org/upload/mig_dec_en.pdf

http://www.un-ngls.org/spip.php?page=article_s\&id_article=703

http://en.wikipedia.org/wiki/International_Trade_Union_Confederation

http://en.wikipedia.org/wiki/World_Federation_of_Trade_Unions

http://en.wikipedia.org/wiki/International_Chamber_of_Commerce

\section{Interviews conducted with}

Afro Asian Migrant Center (PCAAM): Father Martin Mc Dermott

Embassy of the Republic of the Philippines: His Excellency the Ambassador Mr Gilberto G.B ASUQUE

Embassy of Sri Lanka: Mr WM Premarathna

Caritas Migrant: Ms Najla Chahda (Director of Caritas Migrant)

Ministry Of Labor: Mr Ziad Sayegh (Minister’s team Leader- Policy advisor)

The middle East Council of Churches (MECC): Mrs Seta Hadeshian (Director Unit on Diakonia \& Social Justice)

Hasna Reda - Lawyer and Activist

Simel Esim \& Gudrun Jevne - Gender and Women workers' specialist / ILO Regional Office For Arab States 
Farah Salka - Aanti Racisim Mouvement coordinator /Nasawiya - IndyAct

Ali Fakhry - Antin Racisim Mouvement Program coordinator / Indyact

Nadim Houri - Senior Researcher - Human Right Watch 